\title{
Shear-Wave Velocity Characterization of the USGS Hawaiian Strong-Motion Network on the Island of Hawaii and Development of an NEHRP Site-Class Map
}

\author{
by Ivan G. Wong, Kenneth H. Stokoe II, Brady R. Cox, Jiabei Yuan, Keith L. Knudsen, \\ Fabia Terra, Paul Okubo, and Yin-Cheng Lin
}

\begin{abstract}
To assess the level and nature of ground shaking in Hawaii for the purposes of earthquake hazard mitigation and seismic design, empirical groundmotion prediction models are desired. To develop such empirical relationships, knowledge of the subsurface site conditions beneath strong-motion stations is critical. Thus, as a first step to develop ground-motion prediction models for Hawaii, spectralanalysis-of-surface-waves (SASW) profiling was performed at the 22 free-field U.S. Geological Survey (USGS) strong-motion sites on the Big Island to obtain shear-wave velocity $\left(V_{S}\right)$ data. Nineteen of these stations recorded the 2006 Kiholo Bay moment magnitude (M) 6.7 earthquake, and 17 stations recorded the triggered M 6.0 Mahukona earthquake. $V_{S}$ profiling was performed to reach depths of more than $100 \mathrm{ft}$. Most of the USGS stations are situated on sites underlain by basalt, based on surficial geologic maps. However, the sites have varying degrees of weathering and soil development. The remaining strong-motion stations are located on alluvium or volcanic ash. $V_{S 30}$ (average $V_{S}$ in the top $30 \mathrm{~m}$ ) values for the stations on basalt ranged from 906 to $1908 \mathrm{ft} / \mathrm{s}$ [National Earthquake Hazards Reduction Program (NEHRP) site classes $\mathrm{C}$ and D], because most sites were covered with soil of variable thickness. Based on these data, an NEHRP site-class map was developed for the Big Island. These new $V_{S}$ data will be a significant input into an update of the USGS statewide hazard maps and to the operation of ShakeMap on the island of Hawaii.
\end{abstract}

\section{Introduction}

On 15 October 2006, the island of Hawaii was struck by two earthquakes of moment magnitudes (M) 6.7 and 6.0 (Earthquake Engineering Research Institute, 2006; Fig. 1). The Kiholo Bay mainshock occurred at a depth of $39 \mathrm{~km}$ and provided the largest suite of strong-motion records ever produced for an earthquake in Hawaii and the best opportunity to understand the processes of strong ground shaking in the region. The mainshock is also among the largest events to have occurred in Hawaii since written records have been maintained. The shallower M 6.0 Mahukona earthquake, triggered 7 minutes after the mainshock, occurred at a depth of $19 \mathrm{~km}$. For many, the Kiholo Bay earthquake served as a reminder that Hawaii is not only volcanically but seismically active, and it is exposed to a significant seismic hazard. Klein et al. (2001) indicate that the Big Island possesses one of the highest levels of seismic hazards in the United States. Although no deaths or serious injuries were reported in the Kiholo Bay earthquake, damage estimates exceeded
\$200 million, resulting in the declaration of the Kiholo Bay event as a major disaster area by the U.S. government. Most of the damage was on the islands of Hawaii and Maui and was predominantly nonstructural (Earthquake Engineering Research Institute, 2006). Limited structural damage occurred to older, weaker buildings, including Hawaii's unique post-and-pier and single-wall buildings. Over 1800 individual residences were damaged to varying degrees or one of every 25 homes on the Big Island (Earthquake Engineering Research Institute, 2006).

The mainshock was recorded by 19 strong-motion instruments operated on the Big Island by the U.S. Geological Survey (USGS) as part of the Hawaiian Strong Motion Network (Fig. 1; Table 1) and seven distant stations on Maui and Oahu (Stephens et al., 2007). In addition to the mainshock, the M 6.0 Mahukona event and a deep M 5.0 Puako aftershock were recorded on 17 and 13 stations, respectively. Mainshock peak horizontal ground accelerations (PGAs) 


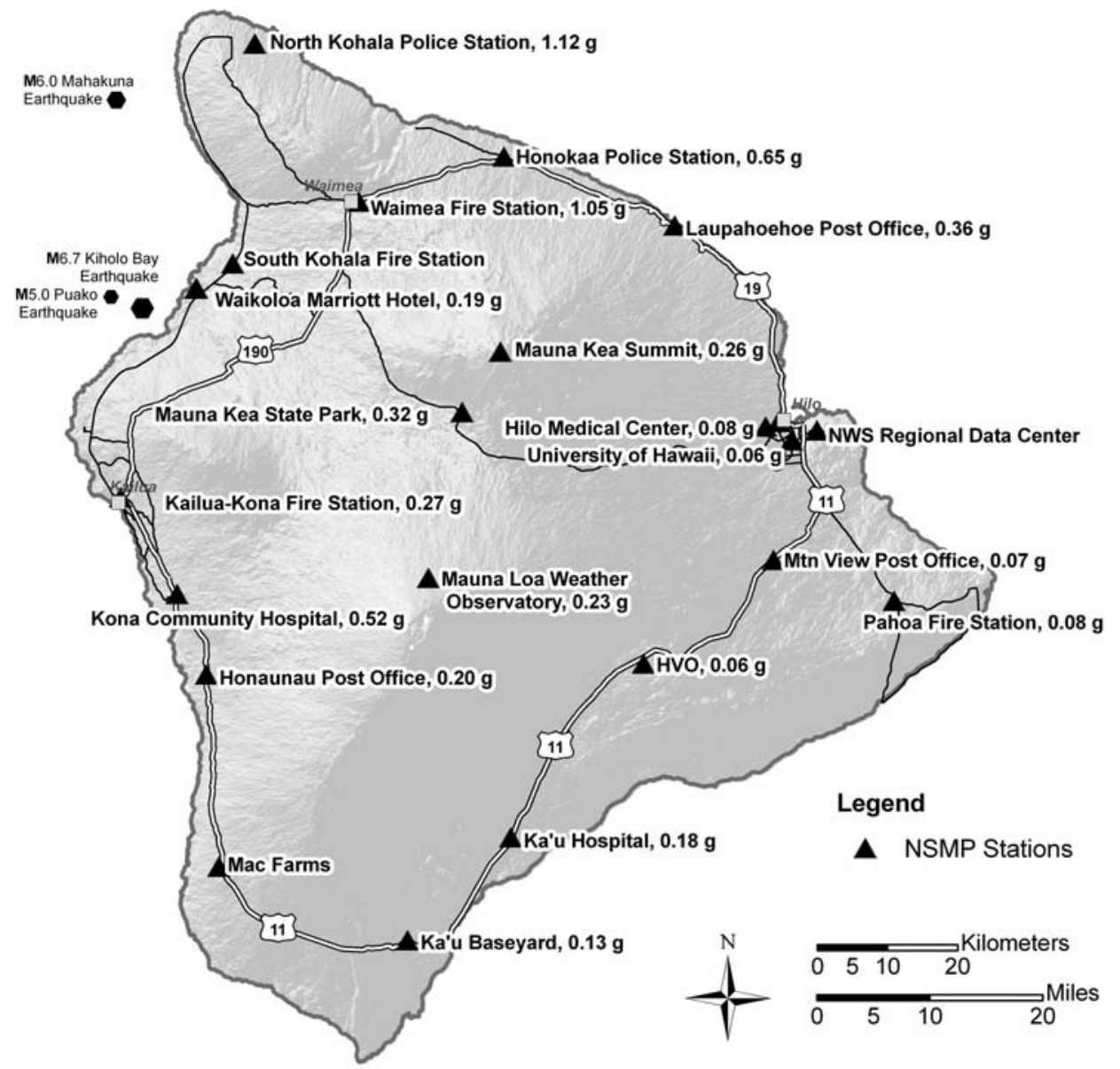

Figure 1. USGS strong-motion stations and recorded PGAs from the 2006 M 6.7 Kiholo Bay mainshock.

Table 1

PGA Values Recorded in the 2006 Kiholo Bay $M 6.7$ and Mahukona $M$ 6.0 Earthquakes

\begin{tabular}{lcccc}
\hline \multicolumn{1}{c}{ Station Name } & $\begin{array}{c}\text { Hypocentral Distance } \\
\text { to Kiholo Bay Mainshock }(\mathrm{km})\end{array}$ & PGA $(g)$ & $\begin{array}{c}\text { Hypocentral Distance } \\
\text { to Mahukona Event }(\mathrm{km})\end{array}$ & PGA $(g)$ \\
\hline Waikoloa Marriott Hotel, Anaehoomalu & 39.5 & 0.19 & 31.6 & 0.17 \\
Kailua-Kona Fire Station & 46.9 & 0.27 & 56.5 & 0.06 \\
Waimea Fire Station & 50.9 & 1.05 & 40.3 & 0.17 \\
Kona Community Hospital, Kea Lakekua & 55.4 & 0.52 & 70.2 & 0.03 \\
North Kohala Police Station, Kapaau & 56.8 & 1.12 & 29.1 & 0.26 \\
Mauna Kea State Park & 59.2 & 0.32 & 65.9 & 0.09 \\
Mauna Kea Summit & 62.4 & 0.26 & 65.8 & 0.02 \\
Honaunau Post Office & 64.4 & 0.20 & 81.7 & 0.05 \\
Mauna Loa Weather Observatory & 66.0 & 0.23 & 80.5 & 0.04 \\
Honokaa Police Station & 66.7 & 0.65 & 57.9 & 0.03 \\
Laupahoehoe Post Office & 84.0 & 0.36 & 82.3 & 0.02 \\
Hawaiian Volcano Observatory (HVO) & 93.2 & 0.06 & 108.7 & 0.02 \\
Hilo Medical Center & 95.9 & 0.08 & 103.2 & 0.01 \\
USDA Laboratory, Hilo & 97.4 & 0.24 & 104.5 & 0.03 \\
Ka'u Hospital, Pāhala & 97.5 & 0.18 & 117.5 & 0.03 \\
University of Hawaii, Hilo & 99.5 & 0.06 & 107.3 & 0.01 \\
Mountain View Post Office & 101.7 & 0.07 & - & - \\
Ka'u Baseyard, Waiohinu & 103.2 & 0.13 & - & - \\
Pahoa Fire Station & 118.6 & 0.08 & 130.8 & 0.01 \\
\hline
\end{tabular}

PGA values from Stephens et al. (2007). Events were not recorded at Mac Farms (Honomalino), South Kohala Fire Station (Kamuela), and NWS Data Regional Center (Hilo), which were installed after the 2006 earthquakes. Mahukona earthquake was not recorded at the Mountain View Post Office and Ka'u Baseyard. 
ranged up to $1.12 \mathrm{~g}\left(\mathrm{~g}=980 \mathrm{~cm} / \mathrm{s}^{2}\right)$ at the North Kohala Police Station (C. Stephens, USGS, written communication, 2007) (Fig. 1; Table 1). The Waimea Fire Station recorded $1.05 \mathrm{~g}$. Such high PGAs are surprising given the depth of the earthquake. The highest recorded PGA for the Mahukona event was $0.26 \mathrm{~g}$ also at the North Kohala Police Station (Table 1).

To be able to utilize the strong-motion data, knowledge of the subsurface site conditions beneath the USGS stations is required. The subsurface geology, and more importantly, the shear-wave velocity $\left(V_{S}\right)$ structure beneath the USGS stations have generally been unknown to date, although the vast majority of stations were installed between 1976 to 1980 . Munson and Thurber (1997) measured $V_{S}$ at three of the current stations using seismic refraction but only to depths of 3 to $5 \mathrm{~m}$. $V_{S}$ information to a depth of at least $30 \mathrm{~m}(100 \mathrm{ft})$ is invaluable to develop Hawaii-specific ground-motion prediction equations, to verify the appropriateness of the groundmotion models being used in the state hazard maps produced by the USGS and in site-specific hazard analyses for engineering design.

The ground-motion prediction models that have been used in the state hazard maps developed by the USGS as part of the National Hazard Mapping Project (Klein et al., 2001) included only one model based on Hawaiian strong-motion data. The relationship by Munson and Thurber (1997) was developed from strong-motion data of Hawaiian earthquakes (22 events, M 4.0 to 7.2, 51 PGA values), but for shallow crustal events and for PGA only. They classified sites as either basalt or ash. The USGS used the Youngs et al. (1997) model for deep earthquakes $(>20 \mathrm{~km})$, although the model was developed for Wadati-Benioff zone events because no ground-motion prediction equations for deep Hawaiian earthquakes were available at the time.

Very recently, Atkinson (2010) has developed a model for both shallow (depth $<20 \mathrm{~km}$ ) and deep earthquakes (35 to $40 \mathrm{~km}$ ) using the referenced empirical approach and the strong-motion database including the 2006 earthquakes. Our $V_{S}$ database was not available at the time Atkinson (2010) was developing her model, but she has evaluated it subsequently with our database. We are currently developing a relationship for deep earthquakes using the stochastic point-source ground-motion numerical modeling approach calibrated with the available deep earthquake strong-motion data.

To obtain $V_{S}$ information beneath the 22 USGS freefield strong-motion sites on the Big Island, spectralanalysis-of-surface-waves (SASW) surveys were performed by the University of Texas, Austin (UT); the University of Arkansas; and URS Corporation (Wong et al., 2008). The following describes the results of those surveys and the development of an NEHRP site-class map for the island of Hawaii, which is critical input into both building code-based and site-specific seismic design. $V_{S}$ information will also be an important input into the operation of ShakeMap on the Big Island. Note a mixture of English and metric units are used in this paper. The SASW surveys and data analyses were performed using feet, so the SASW results are reported in those units. All other units are metric.

\section{Seismotectonic and Geologic Setting}

The Big Island is one of the most seismically active regions in the United States, with seismicity and seismic hazard on par with coastal California, although it is far from a tectonic plate boundary. Most of the seismicity is at least indirectly related to volcanism, explaining why $43 \mathbf{M}>6$ earthquakes have occurred on the volcanically active Big Island since 1868 , whereas only 8 such events have occurred in the rest of the Hawaiian Island chain (Klein et al., 2001). Earthquakes in Hawaii fall into several categories. Most are concentrated under the active volcanoes of Mauna Loa, Kilauea, and Hualalai and are related to the migration and intrusion of magma under and into the volcanoes. Small earthquakes caused by migration of magma often occur in shallow swarms, especially preceding an eruption. Hundreds of such earthquakes may occur in the days leading up to an eruption, but they rarely cause significant damage. In addition, many of Hawaii's largest earthquakes are related to magma injection along major rift zones that flank the active volcanoes. Intrusions of magma into the rifts introduce compressive stresses that are stored in the adjacent rock to be released periodically in large earthquakes. These earthquakes are triggered when the seaward block flanking the rift zone slips laterally on a subhorizontal décollement away from the rift as it makes way for intruding magma and relieves the stored stress (Klein et al., 2001). These décollements are typically 8 to $10 \mathrm{~km}$ deep and lie at the boundary between old oceanic crust and the relatively newly emplaced volcanic edifice. Two of Hawaii's largest historical earthquakes, the 1975 M 7.2 Kalapana earthquake and the 1868 M 7.9 Ka'u district earthquake, both occurred as a result of such décollement slip. The largest historical Hawaiian earthquake was the 2 April 1868 earthquake, which occurred in the Ka'u district along Mauna Loa's southeastern flank, and had an estimated magnitude of $\mathbf{M}$ 7.9.

Another category of earthquakes in Hawaii is indirectly related to volcanism and includes earthquakes that occur primarily in the upper mantle (i.e., 20 to $60 \mathrm{~km}$ deep). These earthquakes tend to occur in a ring surrounding the island and are probably caused by fracturing in response to lithospheric flexure under the weight of the overlying volcanic edifice. Earthquakes of this type include the 1938 M 7 Maui, the 1973 M 6.2 Honomu, and the 2006 Kiholo Bay earthquakes.

Based on the USGS Hawaii state hazard maps, PGA values for a $2 \%$ exceedance in 50 years (return period of 2475 years) on the Big Island range up to $1.8 \mathrm{~g}$ on the South Coast (Klein et al., 2001). In the area of Kiholo Bay, the PGAs are up to $0.8 \mathrm{~g}$. The state hazard maps are for an NEHRP B/C site class, that is, $V_{S 30}$ (average $V_{S}$ in the top $30 \mathrm{~m}$ ) of $760 \mathrm{~m} / \mathrm{s}$ 
$(2493 \mathrm{ft} / \mathrm{s})$. As discussed later, $2493 \mathrm{ft} / \mathrm{s}$ is higher than any $V_{S 30}$ value measured on the Big Island.

The island of Hawaii is composed of eruptive products from five distinct volcanoes; they are, from oldest to youngest, Kohala, Hualalai, Mauna Kea, Mauna Loa, and Kilauea (Wolfe and Morris, 1996). Kilauea and Mauna Loa are very active shield-stage volcanoes whose lava is generally composed of tholeiitic basalt. Hualalai, Mauna Kea, and Kohala are all capped by postshield lavas, which are more alkalic than the shield-stage basalt.

Major geologic map units and their ages on the Big Island include Puna (Holocene), Hilina (Pleistocene), Ka'u (Holocene and Pleistocene), Kahuku (Pleistocene), and Ninole (Pleistocene) basalts of Kilauea; the Hualalai basalt (Holocene and Pleistocene); Laupahoehoe (Holocene and Pleistocene), Hamakua (Pleistocene), Hawi (Pleistocene), and Polohu (Pleistocene) volcanics of Mauna Kea, Pāhala Ash, and smaller landslide deposits, alluvium and colluvium, eolian deposits, slope deposits, and artificial fill (Wolfe and Morris, 1996). Only the Pāhala Ash is found in any abundance. The ash is a deeply weathered ash that can be as much as $15 \mathrm{~m}$ thick and predates the earliest Holocene lavas on Kilauea and Mauna Loa. Detailed descriptions of these units are presented on Table 2.

\section{SASW Methodology}

The $V_{S}$ structure at each site was measured using the SASW technique. The SASW method is widely accepted and has been applied to numerous soil and rock sites (Stokoe et al., 1994, 2004). In particular, the SASW method has often been applied to the problem of characterizing materials for near-surface site response analysis (Rosenblad et al., 2001; Wong and Silva, 2006).

The SASW methodology is a nondestructive and nonintrusive seismic method. It utilizes the dispersive nature of Rayleigh-type surface waves propagating through a layered material to estimate the $V_{S}$ profile of the material (Stokoe et al., 1994). In this context, dispersion arises when surfacewave velocity varies with wavelength or frequency. Dispersion in surface-wave velocity arises from changing stiffness properties of the soil and rock layers with depth. This phenomenon is illustrated in Figure 2 for a multilayered solid. A high-frequency surface wave, which propagates with a short wavelength, only stresses material near the exposed surface and thus only samples the properties of the shallow, nearsurface material (Fig. 2b). A lower-frequency surface wave, which has a longer wavelength, stresses material to a greater depth and thus samples the properties of both shallower and deeper materials (Fig. 2c). Spectral analysis is used to separate the waves by frequency and wavelength to determine the experimental (field) dispersion curve for the site via phase unwrapping. An effective/superposed-mode inversion that takes into account ground motions induced by fundamental and higher-mode surface waves as well as body waves (i.e., a full wavefield solution) is then used to match theoretically the field dispersion curve with a 1D layered system of varying layer stiffnesses and thicknesses (Joh, 1996). The 1D $V_{S}$ profile that generates a dispersion curve that best matches the field dispersion curve is selected as the site profile. The 1D geometry is an important assumption. Departures from this geometry, such as when velocity layers are dipping, can result in considerable variability in the dispersion curves and hence multiple interpretations.

SASW measurements involve generating surface waves at one point on the ground surface and recording them as they pass by pairs of receivers at multiple locations. All measurement points are arranged along a single radial path from the source. Successively longer spacings between the receiver pairs and between the source and first receiver in the pair are typically used to measure progressively longer wavelengths. The distance between the source and first receiver in the pair $(d)$ is typically kept equal to the distance between receivers in the pair in order to mitigate near-field effects. Measurements are performed with several (typically seven or more) sets of source-receiver pair spacings. Phase plots from surface waves propagating between each receiver pair are recorded. From each phase plot, the phase velocity of the surface wave can be calculated at each frequency from (Joh, 1996):

$$
V_{R}=f \times \frac{360}{\phi} \times d,
$$

where $V_{R}$ is the phase velocity in $\mathrm{ft} / \mathrm{s}$ or $\mathrm{m} / \mathrm{s}, f$ is the frequency in Hertz (cycles/s), $\phi$ is the phase angle in degrees (at frequency $f$ ), and $d$ is the distance between the receivers in the same length units used to represent $V_{R}$. From this calculation, a plot of phase velocity versus frequency, called an individual dispersion curve, is generated. This procedure is repeated for all receiver spacings used at the site and typically involves significant overlapping in the dispersion data between adjacent receiver sets. The individual dispersion curves from all receiver spacings are combined into a single composite dispersion curve called the experimental or field dispersion curve, which contains literally hundreds of individual dispersion measurements. The composite dispersion curve is compacted by using a combined polynomial fit and a moving average analysis procedure. Once the compacted dispersion curve is generated, an iterative forward modeling procedure is used to create a theoretical dispersion curve to match the observed curve (Joh, 1996). The stiffness profile that provides the best match to the observed dispersion curve is presented as the $V_{S}$ profile at the site.

The SASW method is cost effective and well-suited for in situ testing. The method has been validated at numerous sites in blind comparisons. For example, downhole, OYO suspension, and SASW $V_{S}$ profiles were compared at Yucca Mountain, Nevada (Stokoe et al., 2003), and Imperial Valley, California (Lin et al., 2008); the results indicated generally good agreement even though the techniques are characterizing different volumes of the subsurface. Both downhole and 
Table 2

Island of Hawaii Site Response Units and NEHRP Site Classes

\begin{tabular}{|c|c|c|c|c|c|c|c|c|}
\hline \multirow[b]{2}{*}{ Map Unit* } & \multicolumn{6}{|c|}{$V_{S 30}(\mathrm{ft} / \mathrm{s})$} & \multirow[b]{2}{*}{ NEHRP Site Class ${ }^{\dagger}$} & \multirow[b]{2}{*}{ Notes } \\
\hline & $\mathrm{N}^{\ddagger}$ & Min & $\operatorname{Max}$ & Log Mean & Median & $\pm \sigma$ & & \\
\hline Basalt & 19 & 890 & 1902 & 1312 & 1365 & 257 & $\mathrm{C}$ or $\mathrm{D}$ & $\begin{array}{l}\text { Includes all basalt/lava units (including lava flows, } \\
\text { scoria cones, littoral deposits, spatter or tuff cones, } \\
\text { cinder cones, lava domes). About } 75 \text { geologic map } \\
\text { units are included in this category. }\end{array}$ \\
\hline Ash/tephra & 2 & 437 & 1430 & NA & NA & NA & $\mathrm{D}$ or $\mathrm{E}$ & $\begin{array}{l}\text { Includes map unit Qt and map units from each } \\
\text { volcano. Low on west flank of Mauna Kea, } \\
\text { comprises unconsolidated, crossbedded, very fine } \\
\text { grained to fine grained dune sand and loess } \\
\text { blankets interpreted as deposits of wind-reworked } \\
\text { ash derived from eruptions at vents of the } \\
\text { Laupāhoehoe Volcanics (units Qlcy, Qlc, Qlbc) } \\
\text { (Wolfe and Morris, 1996; Porter, 1997). Deeply } \\
\text { weathered elsewhere on Island of Hawai'i where } \\
\text { encompassing the Pāhala Ash, a stratigraphic name } \\
\text { applied by Wolfe and Morris (1996) to both } \\
\text { primary and reworked tephra-fall deposits that } \\
\text { originated from Kīlauea, Mauna Loa, Mauna Kea, } \\
\text { and perhaps Kohala volcanoes. Sherrod et al. } \\
\text { (2007) reserve the name Pāhala Ash for deposits } \\
\text { on the south side of the Island. Younger tephra of } \\
\text { Kīlauea has been mapped as units within } \\
\text { encompassing volcanic formations; for example, } \\
\text { Keanakāko'i Ash Member is labeled as ash beds of } \\
\text { age } 200 \text { to } 500 \text { yr within the Puna Basalt (unit } \\
\text { Qpa4) (Sherrod } \text { et al., 2007). }\end{array}$ \\
\hline Alluvium & 1 & 1176 & 1176 & NA & NA & NA & $\mathrm{D}$ or $\mathrm{E}$ & $\begin{array}{l}\text { Unconsolidated deposits of silt, sand, and gravel } \\
\text { along streams and in valley bottoms (Sherrod et al., } \\
\text { 2007). Includes interlayered fluvial, eolian, debris- } \\
\text { flow, and tephra-fall deposits on south flank of } \\
\text { Mauna Kea. }\end{array}$ \\
\hline Glacial deposits & 0 & - & - & - & - & - & $\mathrm{C}$ or $\mathrm{D}$ & $\begin{array}{l}\text { Till and outwash on Mauna Kea (Sherrod et al., } \\
\text { 2007). }\end{array}$ \\
\hline Artificial fill & 2 & 1250 & 1439 & NA & NA & NA & $\mathrm{D}$ or $\mathrm{E}$ & $\begin{array}{l}\text { Manmade fill forming piers and harbor breakwaters } \\
\text { along coastline (Sherrod et al., 2007). } \$\end{array}$ \\
\hline Landslide deposits & 0 & - & - & - & - & - & $\mathrm{C}$ or $\mathrm{D}$ & $\begin{array}{l}\text { Some deposits incorporated preexisting volcanic ash } \\
\text { deposits, which locally contribute high proportion } \\
\text { of matrix, as in the Wood Valley area on south } \\
\text { flank of Mauna Loa (Sherrod et al., 2007). }\end{array}$ \\
\hline Sand dunes & 0 & - & - & - & - & - & $\mathrm{D}$ & $\begin{array}{l}\text { Map unit Qdy. Unconsolidated, mostly coralline sand } \\
\text { forming eolian sheets and dunes, found chiefly } \\
\text { adjacent to beach deposits. On Kīlauea volcano, } \\
\text { comprises black glassy and lithic sand reworked } \\
\text { downwind onto the volcano's southwest rift zone } \\
\text { from } 200 \text { to } 500 \text {-yr-old tephra deposits in the } \\
\text { summit area (Sherrod et al., 2007). }\end{array}$ \\
\hline
\end{tabular}

*Map units are from Sherrod et al. (2007).

${ }^{\dagger} \mathrm{NEHRP}$ site classes based on $V_{S 30}(\mathrm{ft} / \mathrm{s})$ either directly measured or inferred; A, $V_{S 30}>5000 ; \mathrm{B}, 2500<V_{S 30}<5000 ; \mathrm{C}, 1200<V_{S 30}<2500 ; \mathrm{D}$, $600<V_{S 30}<1200 ; \mathrm{E}, V_{S 30}<600$

${ }^{\ddagger}$ Number of SASW measurements.

${ }^{\S}$ Two measurements were made at Kawaihae Harbor where the fill is only about $10 \mathrm{ft}$ thick. The underlying units are coralline sand deposits about 30 to $60 \mathrm{ft}$ thick and basalt.

suspension techniques measure the volume immediately near the borehole, and SASW characterizes the volume below the survey between the source and receivers. The 1D profile resulting from SASW is a global average over the measured volume of the subsurface that has been measured at frequencies that are generally at the bandwidth of most engineering relevance of 1 to $10 \mathrm{~Hz}$.

\section{SASW Survey Results}

Until the present study, only a few shallow cone penetrometer test measurements to infer $V_{S}$ in soft soils have been made on the Big Island. The SASW surveys took place from 7 to 17 January 2008. The 22 free-field strong-motion sites surveyed are shown in Figure 1. Most of the sites are fire 


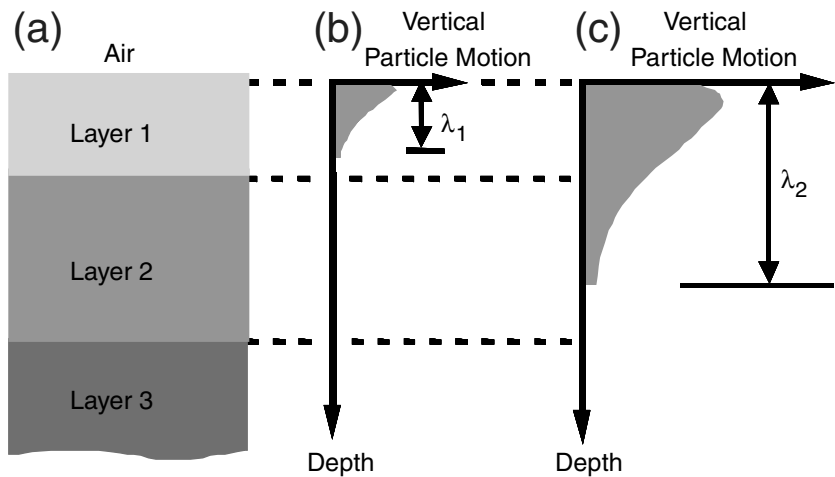

Figure 2. Illustration of surface waves with different wavelengths sampling different materials in a layered system, which results in dispersion in wave velocities: (a) material profile; (b) shorter wavelength, $\lambda_{1}$; and (c) longer wavelength, $\lambda_{2}$.

stations, police stations, hospitals, or post offices. Surveys were generally performed within $100 \mathrm{ft}$ of the location of the USGS strong-motion instrument. For a few sites, this was not possible due to lack of space to perform the surveys so the distance was as much as $200 \mathrm{ft}$.

Active seismic sources are required for the SASW surveys. A sledgehammer was used for the shorter wavelengths, $\lambda$, less than about $50 \mathrm{ft}$. The larger source used to create wavelengths up to about $600 \mathrm{ft}$ long in this study was the National Science Foundation's Network for Earthquake Engineering Simulation (NEES) mobile vibrator called Thumper (Fig. 3). Thumper, housed and operated by the University of Texas, is a moderate- to high-frequency vibrator. Some important characteristics of Thumper are: (1) mounted on a Ford F650 truck, (2) total weight of about 10,000 kg, and (3) two vibrational orientations (field transformable in a few hours), vertical or horizontal. The maximum force output is about $27 \mathrm{kN}$ over the frequency range of 17 to $225 \mathrm{~Hz}$ with the output decreasing outside this frequency band. The relatively low-force output $(27 \mathrm{kN})$ also makes Thumper an excellent vibrator for testing in urban environments where disturbance or possible damage to existing above-ground and belowground facilities might occur.

In the Hawaii surveys, the full output of Thumper was used in the SASW surveys. A stepped sine excitation was used to collect the surface-wave data at all sites. During this excitation, frequencies from about 200 to $2 \mathrm{~Hz}$ were stepped through over a time span of several minutes. The dwell time at low frequencies was greater than at high frequencies to increase the signal-to-noise ratio.

An example composite field dispersion curve collected on the Big Island is presented in Figure 4a. These data were collected at the Pahoa Fire Station using a sledgehammer source with receiver-to-receiver spacings of $6,12,15$, and $30 \mathrm{ft}$ and Thumper as the source with receiver-to-receiver spacings of $25,50,75,100,150$, and $200 \mathrm{ft}$ using 102 points. The theoretical dispersion curve and its fit to the compacted curve developed in the forward modeling process are shown in Figure 4b. The composite field dispersion curve is
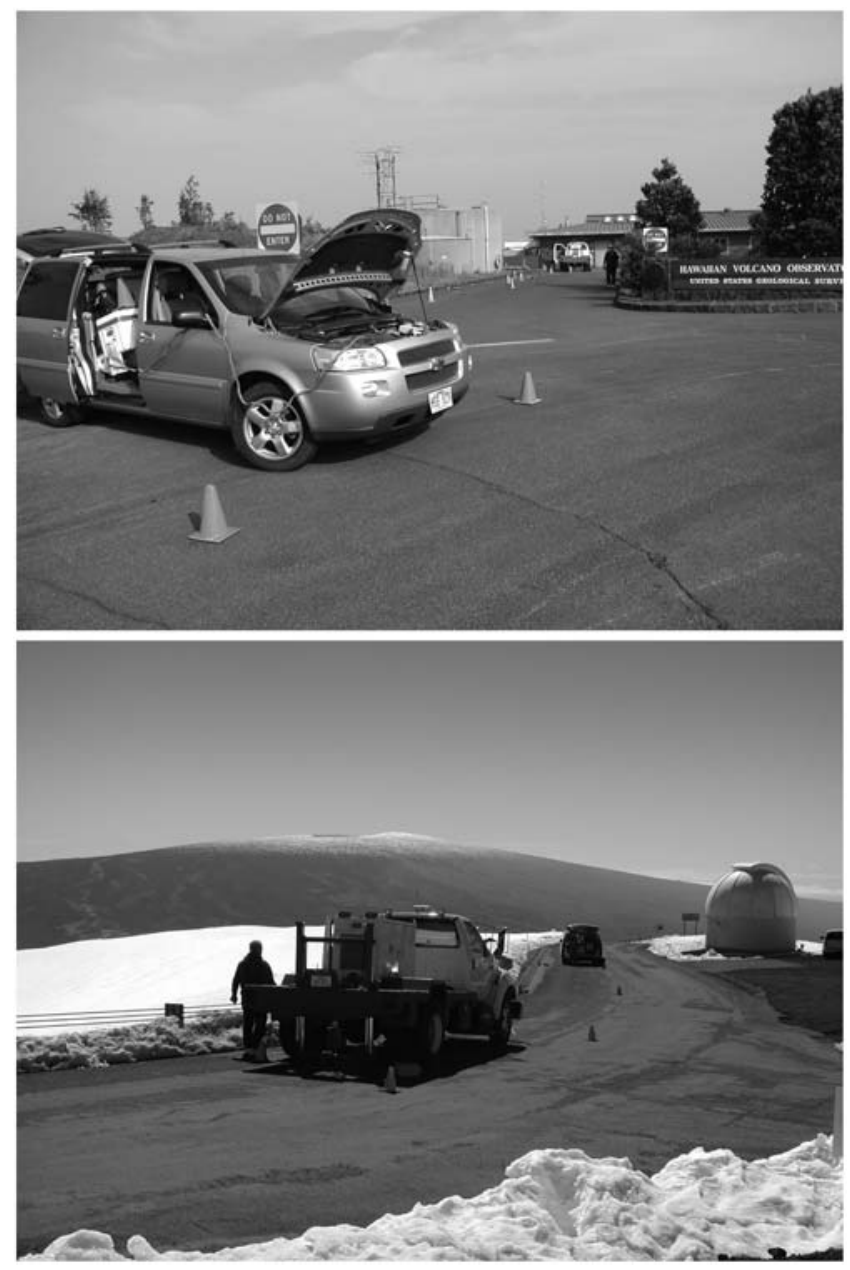

Figure 3. (a) SASW survey in the parking lot at the Hawaiian Volcano Observatory (HVO). Recording and analysis van is in the foreground and Thumper in the far background. (b) Thumper at the top of Mauna Kea. Mauna Loa is in the background.

composed of 3196 data points that cover a frequency range from about 10 to $200 \mathrm{~Hz}$. This frequency range corresponds to a wavelength range of 2.4 to $240 \mathrm{ft}$. The goodness-of-fit between the theoretical and compacted dispersion curves is represented by the root mean square (rms) error in Figure $4 \mathrm{~b}$ and by the mean $(\mu)$ and standard deviation $(\sigma)$ of $\Delta V_{R} / V_{R}$ in Figure $4 \mathrm{c}$, where $V_{R}$ is from the compacted dispersion curve, and $\Delta V_{R}$ is the phase velocity difference between the compacted dispersion curve and theoretical dispersion curve at the same frequency. In this case, the rms error is $59.4 \mathrm{ft} / \mathrm{s}$, and the $\mu$ and $\sigma$ are $-0.5 \%$ and $5.6 \%$, respectively. Typical values found for the 22 sites are rms errors (for $V_{R}$ ) ranging from about 30 to $180 \mathrm{ft} / \mathrm{s}, \mu$ ranging from $-0.4 \%$ to $0.5 \%$, and $\sigma$ ranging from $3.3 \%$ to $6.5 \%$.

In terms of the resolution in the $V_{S}$ profiles, the resolution decreases with depth for all nonintrusive, surface-wavebased methods. For SASW testing on the Big Island, consider the $V_{S}$ profile of the Pahoa Fire Station. This profile consists of nine layers, with the thickness increasing with depth from $1 \mathrm{ft}$ for the top layer to $50 \mathrm{ft}$ for the eighth layer (Fig. 5). 
(a)

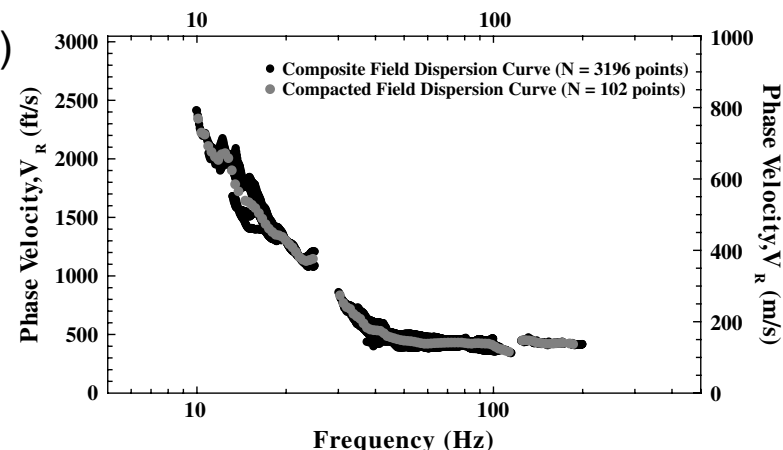

(b)

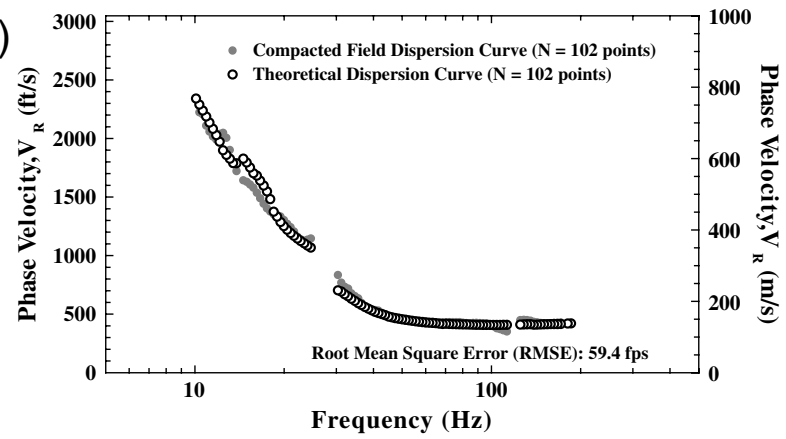

(c)

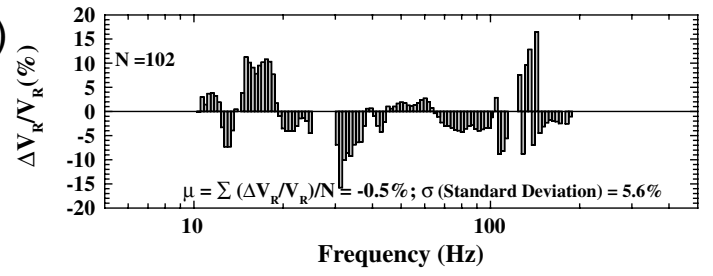

Figure 4. SASW forward modeling process and goodness-of-fit evaluation for the survey at the Pahoa Fire Station: (a) developing the compacted field dispersion curve, (b) fitting the compacted dispersion curve with a theoretical dispersion curve, and (c) determining the mean $(\mu)$ and $\sigma$ of the best fit.

The ninth layer includes the half-space, but only $20 \mathrm{ft}$ of the half-space is presented because the $V_{S}$ profile is shown only to a depth equal to 0.5 times the maximum wavelength in the composite field dispersion curve. This criterion is used so that the resolution of $V_{S}$ in the lower portion of the profile is within $\pm 10 \%$ to $\pm 15 \%$.

To demonstrate this resolution, consider Figure 5a,b, where the value of $V_{S}$ in layer 5 has been varied by $\pm 10 \%$ from the original best-fit profile. As seen in Figure 5b, these $\pm 10 \%$ changes to layer 5 result in theoretical dispersion curves that no longer fit the compacted field dispersion curve. As such, the true $V_{S}$ for layer 5 is well within $10 \%$ in the forward modeling process, and resolution is expected to be even better for the shallower layers. Similarly, in Figure $5 \mathrm{c}, \mathrm{d}$, the $V_{S}$ of layer 8 has been varied by $\pm 10 \%$ from the original best-fit profile. In this case, the fit of the original theoretical dispersion curve is still better than the varied profile, indicating that the original $V_{S}$ profile can be considered, in general terms, to be within $10 \%$ of the true $V_{S}$ value in that depth range over that lateral distance tested. These results are typical of the 22 sites tested on the Big Island.
One of the benefits of SASW is that velocity inversions can be detected. However, the ability to detect these inversions depends on the relative stiffness contrast as well as the inverse layer thickness and its absolute depth below the surface. If a velocity inversion is detected at the site, it will be visible in the experimental dispersion curve, so you will know it is present in the data even before the inversion process. The $V_{S}$ profiles presented herein were not developed simply by setting a predetermined number of layers and letting an automated inversion find the best solution. An iterative forward modeling procedure was used to visually determine a good fit to the data by varying the number and thicknesses of layers. Then an automated inversion was used to refine this visually fit model slightly.

The $V_{S}$ profiles for the 22 surveys at the strong-motion sites are shown in Figures 6 through 11. The profiling depths ranged from 100 to $318 \mathrm{ft}$ (Table 3). For about $1 / 3$ of the sites, the profiling depth was $124 \mathrm{ft}$ or less. In these cases, the shallower profiling depths resulted from one or more of the following: (1) the available space at the site was insufficient for the longer arrays (source to farthest receiver of 400 to $600 \mathrm{ft}$ ) required to profile deeper, (2) there was a significant velocity jump (increase of $40 \%$ or more) in the top $100 \mathrm{ft}$, and (3) there was a substantial thickness (40 ft or more) of soft soil $\left(V_{S}<500 \mathrm{ft} / \mathrm{s}\right)$ in the upper portion of the site.

In the forward modeling of each field dispersion curve, the depth to the water table (10 to $140 \mathrm{ft}$ ) was estimated based on the surrounding topography and elevation relative to the ocean. $P$-wave refraction surveys were tried at three sites to detect the water table. However, it was not found to be successful for several reasons. The authors have found that from a practical standpoint, the more variable the near-surface layering (shallow inversions, gradual stiffness contrasts, etc.), the more difficult it is to analyze the data to locate the water table. Even if strong trends in the wave arrivals are detected, hidden layer effects can mask the true water table depth. Furthermore, the receivers must be placed directly on the native soil and not on asphalt (as in a parking lot), or the direct wave arrival will always be fastest. Many of the test locations required the SASW surveys through a thin layer of asphalt.

Sensitivity analyses indicate that $V_{S}$ profiles are not sensitive to the water table depth once reasonable estimates are included in the modeling process (Wong et al., 2011). Changing the depth to the water table by a factor of 2 at all 22 stations results in $0.0 \%$ difference in $V_{S 30}$ at 19 stations and at most $4.4 \%$ at the Hawaiian Volcano Observatory (HVO).

\section{Geotechnical Site Characterization}

To estimate general categories of geotechnical materials within each profile, the $V_{S}$-depth profiles were subdivided and grouped according to relative trends expected for various geotechnical materials. The template of $V_{S}$-depth trends used 
(a)

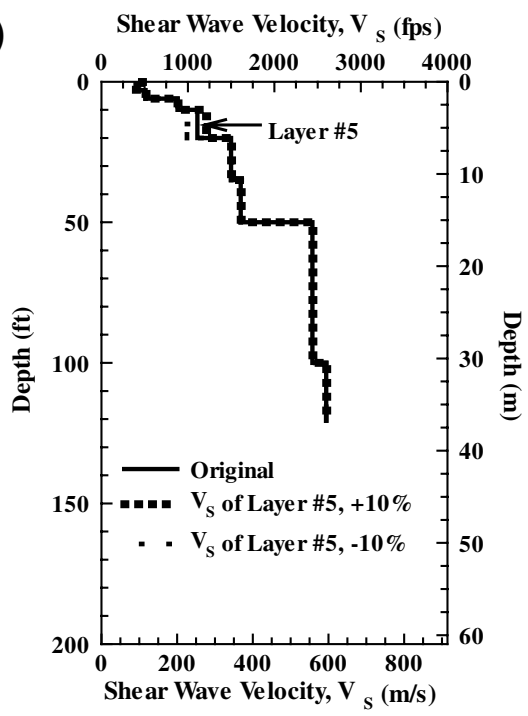

(c)

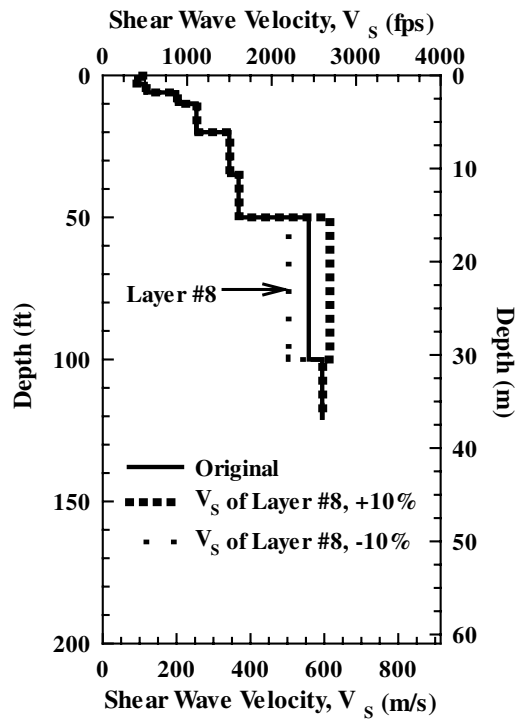

(b)

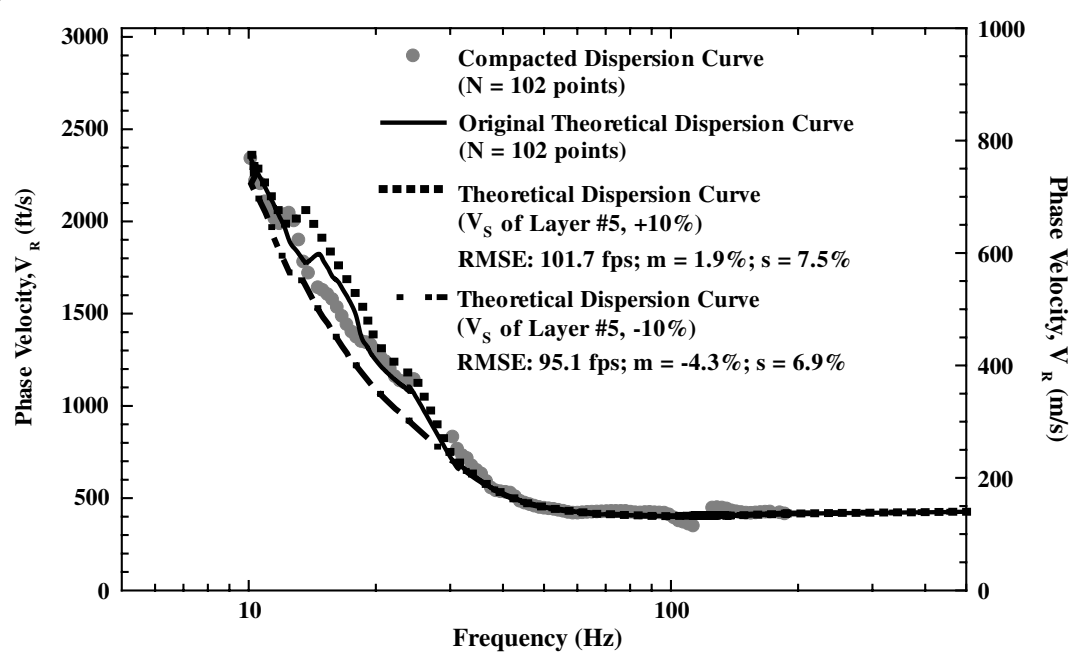

(d)

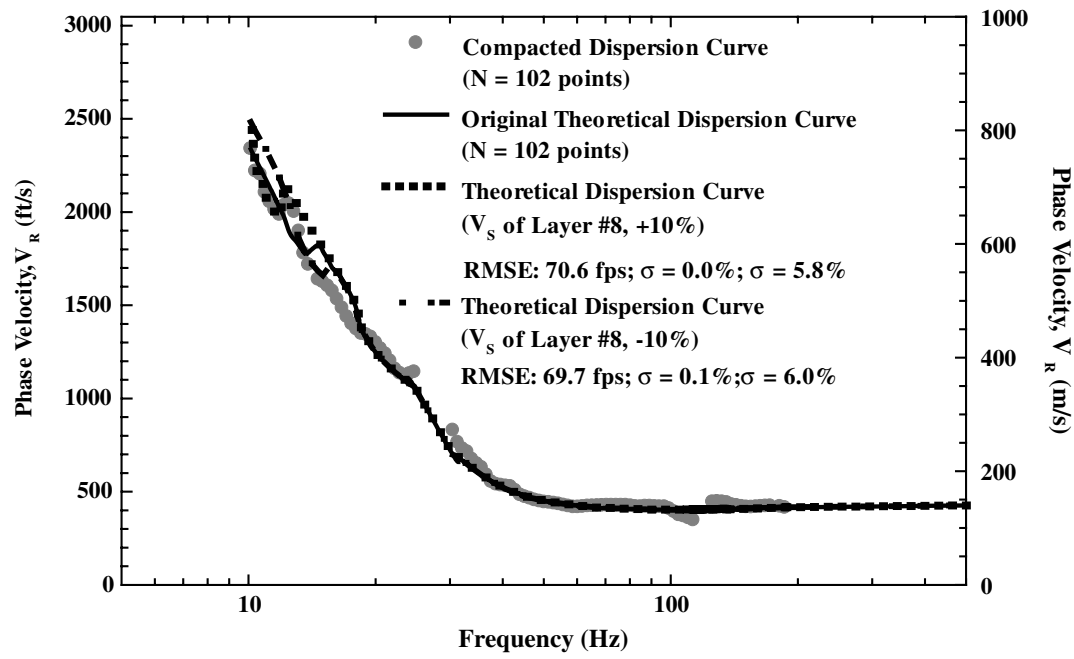

Figure 5. Parametric study of resolution in the $V_{S}$ profile at the Pahoa Fire Station: (a) varying $V_{S}$ of layer \#5, (b) effect on the theoretical dispersion curves, (c) varying $V_{S}$ of layer \#8, and (d) effect on the theoretical dispersion curves.

to categorize the materials is shown in Figure 12. The trend for basalt, referred to as unweathered basalt herein, is defined by any material with $V_{S} \geq 2200 \mathrm{ft} / \mathrm{s}$ at depths $\leq 75 \mathrm{ft}$ and $V_{S} \geq 2500 \mathrm{ft} / \mathrm{s}$ at depths $>75 \mathrm{ft}$ (essentially an NEHRP B material). The trends compared with other materials are based on $V_{S}$-depth relationships of medium dense sand and dense gravel (Menq, 2003). The sand and gravel were each assumed to have relative densities of about $75 \%$ and $95 \%$, respectively, and the water table depth was assumed at $35 \mathrm{ft}$. In terms of site classes, the $V_{S 30}$ values of the sand and gravel are 848 and $1103 \mathrm{ft} / \mathrm{s}$, respectively, which both correspond to NEHRP site class D.

The stiffest material measured at the sites is considered to represent unweathered basalt. This material was encountered within the top $200 \mathrm{ft}$ at 14 sites (Fig. 13). The $V_{S}$ profiles of the unweathered basalt over the depths that they were measured along with the median, and 16th and 84th percentile profiles are shown in Figure 13. The $V_{S}$ values range from 2200 to $3200 \mathrm{ft} / \mathrm{s}$. The coefficient of variation $(\mathrm{COV}=$ standard deviation $[\sigma] /$ mean $)$ and number of profiles are also shown in Figure 13. The COV is quite low $(<0.15)$ over the depth range of about 50 to $200 \mathrm{ft}$, where at least three or more profiles were determined.

The second $V_{S}$-profile group is shown in Figure 14. This group was measured at 16 sites and is defined by: (1) a significant increase in $V_{S}$ with depth in the top $50 \mathrm{ft}$ and (2) median $V_{S}$ values somewhat higher than dense gravel below about $5 \mathrm{ft}$ but considerably less than unweathered basalt in the top $140 \mathrm{ft}$. This group is considered to represent partially weathered basalt that contains some voids, fractures, etc. This material can be seen in some shallow cuts in nearsurface basalt as is present near the Waikoloa Marriott Hotel. The COV of this material decreases with depth in the top $35 \mathrm{ft}$, below which the COV is $\leq 0.12$. 


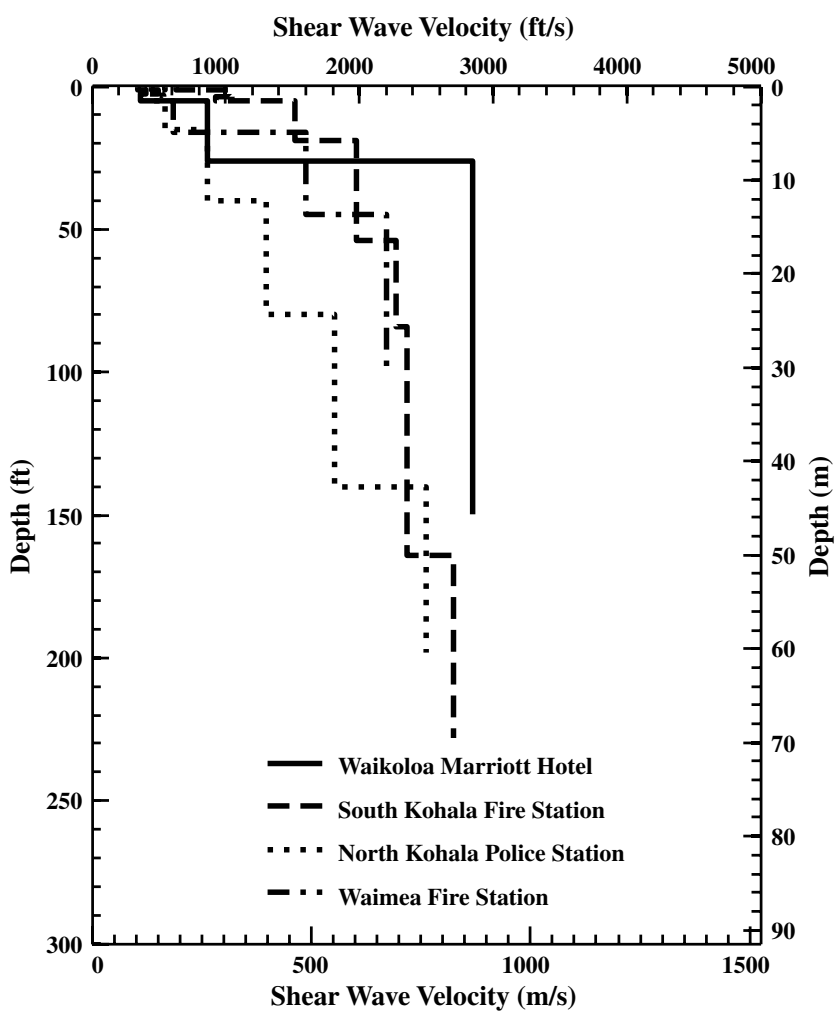

Figure 6. $\quad V_{S}$ profiles at Waikoloa Marriott Hotel, South Kohala Fire Station, North Kohala Police Station, and Waimea Fire Station.

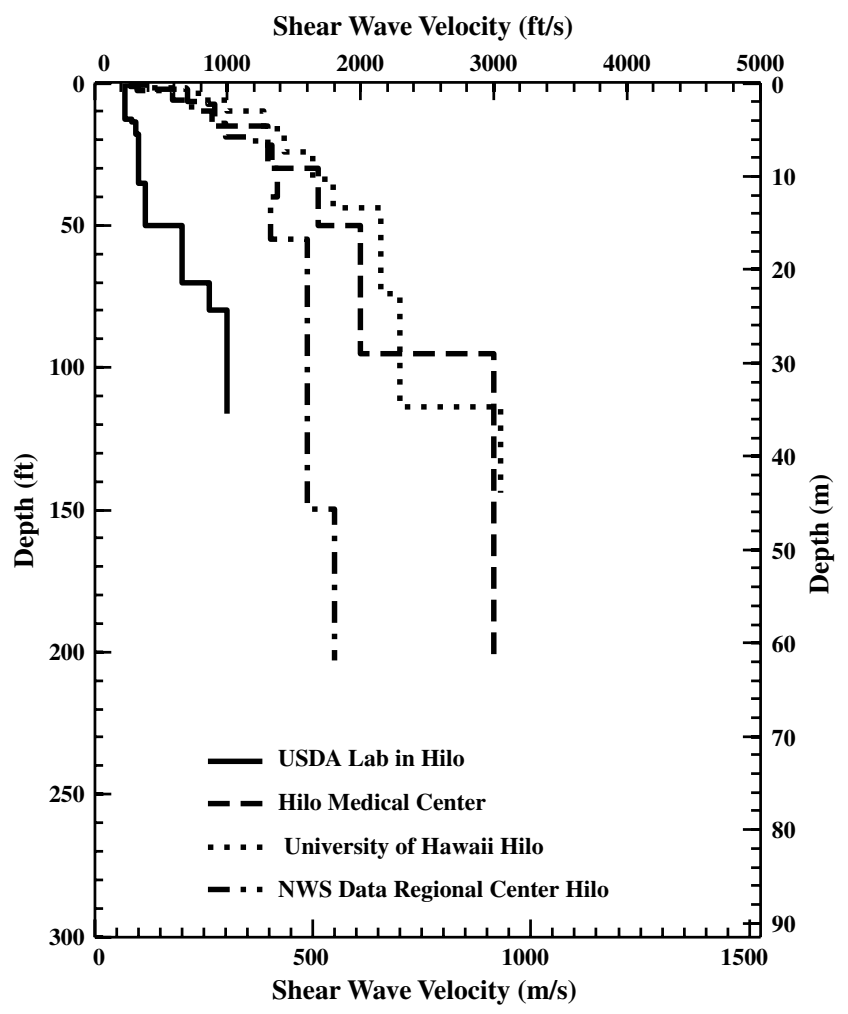

Figure 8. $V_{S}$ profiles at USDA Lab in Hilo; Hilo Medical Center; University of Hawaii, Hilo; and NWS Data Regional Center, Hilo.

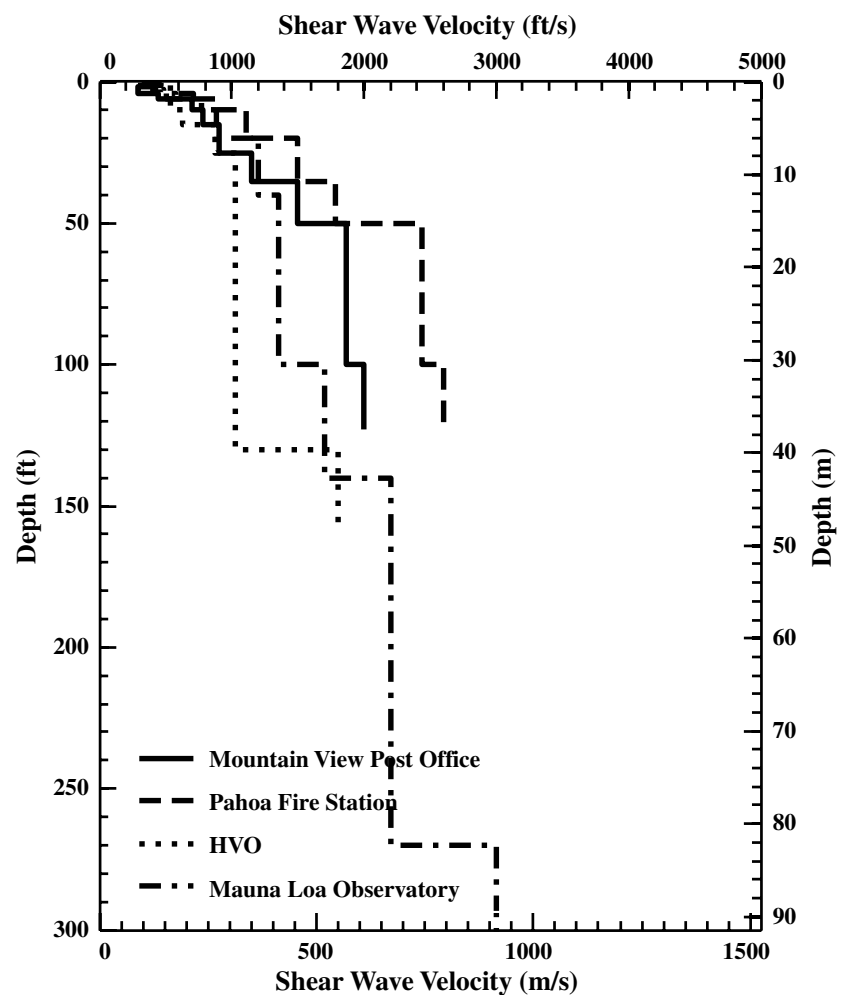

Figure 9. $V_{S}$ profiles at Mountain View Post Office, Pahoa Fire Station, HVO, and Mauna Loa Observatory.
Figure 7. $\quad V_{S}$ profiles at Honokaa Police Station, Laupahoehoe
Post Office, Mauna Kea Summit, and Mauna Kea State Park.

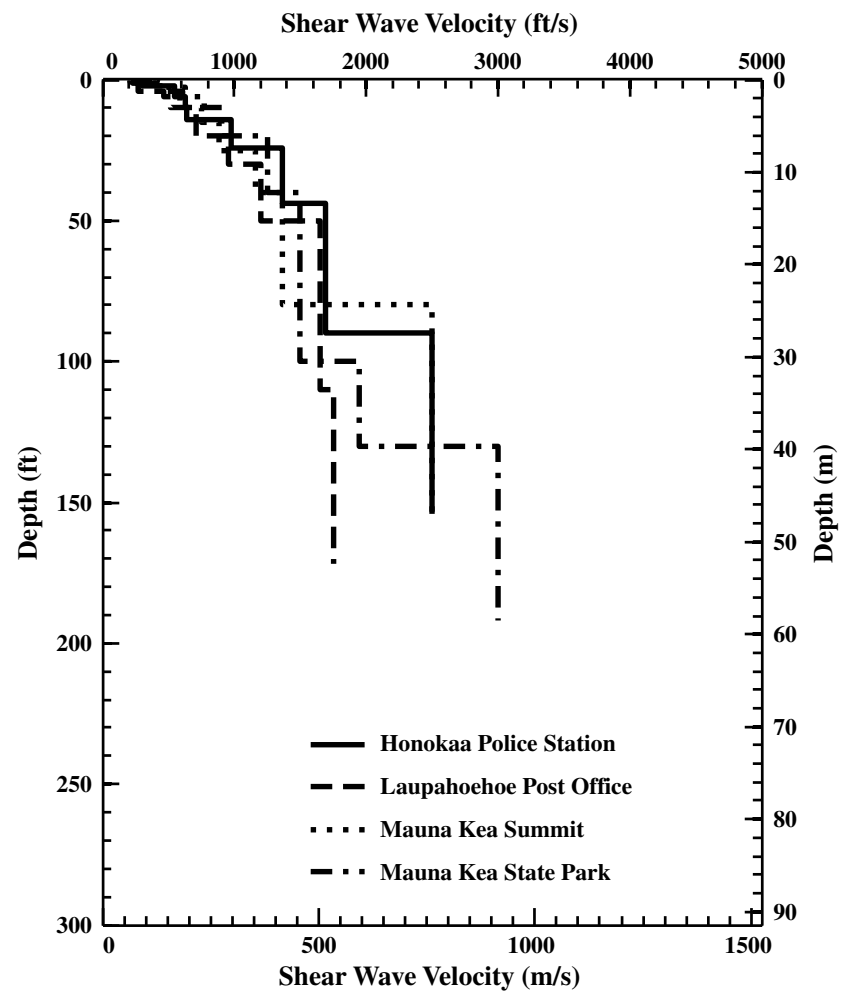




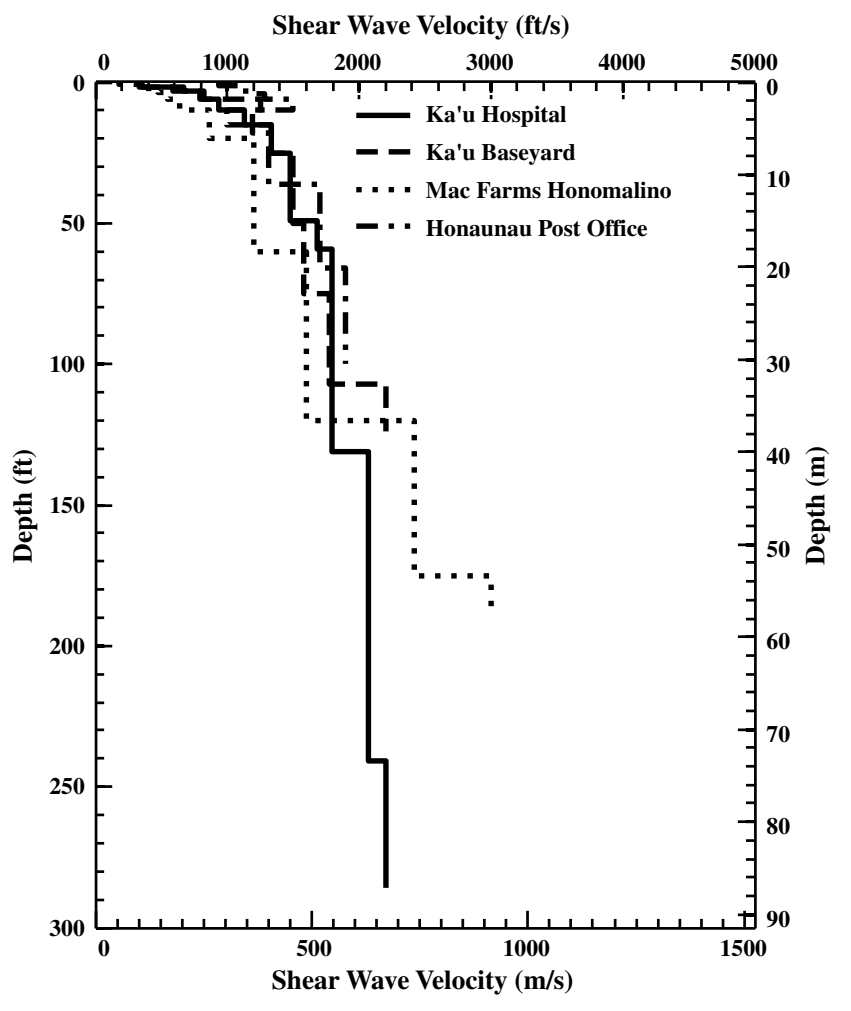

Figure 10. $\quad V_{S}$ profiles at Ka'u Hospital; Ka'u Baseyard; Mac Farms, Honomalino; and Honaunau Post Office.

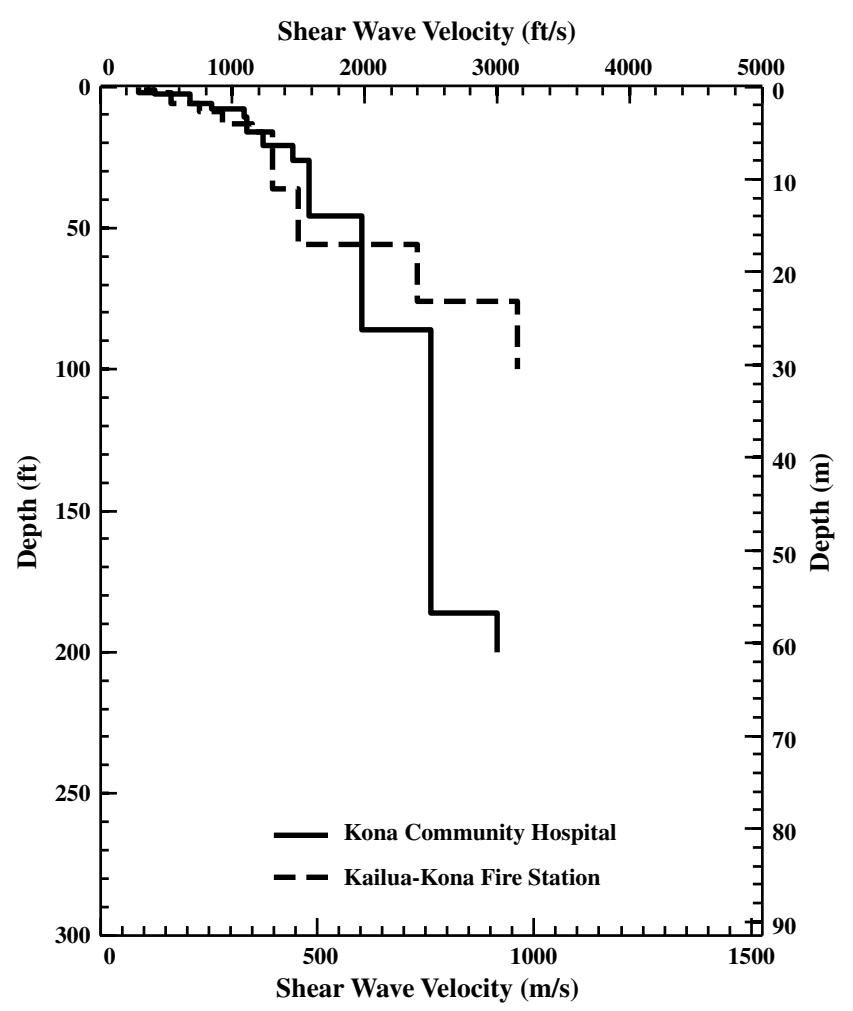

Figure 11. $V_{S}$ profiles at Kona Community Hospital and Kailua-Kona Fire Station.
The third and last grouping is shown in Figure 15. This group was evaluated at 16 sites and is defined by median $V_{S}$ values equal to or slightly above dense gravel at depths greater than $25 \mathrm{ft}$. It is interesting to observe how closely the $V_{S}$-depth trend follows the dense gravel profile. Below about $30 \mathrm{ft}$, the $\mathrm{COV}$ of this material is also $\leq 0.12$. This material is considered to represent stiff soil.

One or more of the three general categories of materials were encountered at 21 of the 22 sites. The thicknesses of these layers in each profile is given in Table 3. As noted previously, the soil identified in the layered profiles in Table 3 is actually the stiff soil group presented in Figure 15. At two sites, the U.S. Department of Agriculture (USDA) Laboratory and the Hawaiian Volcano Observatory (HVO), softer soil was also encountered in the profiles (Figs. 8 and 9).

\section{Strong Motion Sites and the Kiholo Bay Earthquake}

In the following, we discuss the subsurface geologic and $V_{S}$ structure in the context of their possible influence on the recorded ground motions from the 2006 earthquakes. We attempted to corroborate our $V_{S}$ profile results with borehole logs, but attempts to find such information were unsuccessful with the exception of one site. Site selection of the USGS strong-motion sites was not accompanied by any geotechnical site characterization, for example, drilling.

The Waikoloa Marriott Hotel was the closest strongmotion station to the 2006 earthquake and recorded a PGA of $0.19 \mathrm{~g}$ (Table 1). The site is underlain by $26 \mathrm{ft}$ of soil and basalt with a $V_{S}$ of $2850 \mathrm{ft} / \mathrm{s} \mathrm{(Fig.} \mathrm{6).} \mathrm{The} \mathrm{South} \mathrm{Kohala} \mathrm{Fire}$ Station, which was installed after the 2006 earthquake, is underlain by a thin soil layer $(<5 \mathrm{ft})$ and lightly weathered basalt showing a steady $V_{S}$ gradient down to at least a depth of $164 \mathrm{ft}$ (Fig. 6).

The North Kohala Police Station in Kapaau and the Waimea Fire Station recorded the highest PGAs in the 2006 mainshock at more than $1 g$ (Table 1). Both sites show soil over weathered basalt (Fig. 6). The North Kohala Police Station $V_{S}$ profile shows a strong velocity gradient in the top $200 \mathrm{ft}$. The $V_{S}$ profile beneath the Waimea Fire Station shows a 16-ft-thick soil with a low $V_{S}$ of 430 to $610 \mathrm{ft} / \mathrm{s}$ overlying $1600 \mathrm{ft} / \mathrm{s}$ weathered basalt (Fig. 6). Site amplification due to strong velocity contrasts and velocity gradients may account for the high PGA values. This is supported by the observation that the North Kohala Police Station also recorded the highest PGA in the Mahukona earthquake, although it was the closest strong-motion station (Table 1; Fig. 1). The Waimea Fire Station, the third closest station, also recorded a comparatively high PGA in the Mahukona event (Table 1; Fig. 1). There may be other source and path factors coming into play at these two stations including the possibility there may be a directional source effect in the 2006 mainshock ground motions because the three highest recorded PGA values recorded, North Kohala Police Station, Waimea Fire Station, and the Honokaa Police Station, are in the northernmost part of the Big Island (Fig. 1). There were 
Table 3

Site Characteristics and NEHRP Site Classes of the Strong-Motion Stations on the Island of Hawaii

\begin{tabular}{|c|c|c|c|c|c|c|c|}
\hline $\begin{array}{l}\text { Station } \\
\text { No. }\end{array}$ & Station Location & $\begin{array}{l}\text { Longitude } \\
\left({ }^{\circ}\right)\end{array}$ & $\begin{array}{l}\text { Latitude } \\
\left({ }^{\circ}\right)\end{array}$ & $\begin{array}{l}\text { Maximum } \\
\text { Profile } \\
\text { Depth (ft) }\end{array}$ & $\begin{array}{l}V_{S 30} * \\
(\mathrm{ft} / \mathrm{s})\end{array}$ & $\begin{array}{l}\text { NEHRP } \\
\text { Site } \\
\text { Class }^{\dagger}\end{array}$ & $\begin{array}{l}\text { Geotechnical Layering } \\
\text { Profiles Based on } V_{S}^{\ddagger} \\
\end{array}$ \\
\hline 2810 & Kailua-Kona Fire Station & -155.9923 & 19.6477 & 100 & 1418 & $\mathrm{C}$ & $13 \mathrm{ft}$ soil $/ 43 \mathrm{ft}$ weathered basalt/basalt \\
\hline 2812 & Ka’u Hospital, Pāhala & -155.4723 & 19.1999 & 286 & 1389 & $\mathrm{C}$ & $1.5 \mathrm{ft}$ soil $/ 284 \mathrm{ft}^{\S}$ weathered basalt \\
\hline 2816 & Pahoa Fire Station & -154.9466 & 19.4934 & 120 & 1497 & $\mathrm{C}$ & $10 \mathrm{ft}$ soil $/ 40 \mathrm{ft}$ weathered basalt/basalt \\
\hline 2817 & University of Hawaii, Hilo & -155.0805 & 19.7034 & 144 & 1615 & $\mathrm{C}$ & $1.5 \mathrm{ft}$ soil $/ 42.5 \mathrm{ft}$ weathered basalt/basalt \\
\hline 2818 & USDA Laboratory, Hilo & -155.0974 & 19.7277 & 116 & 437 & $\mathrm{E}$ & $70+\mathrm{ft}$ very soft soil $/ 46+\mathrm{ft}$ soft soil \\
\hline 2822 & Ka'u Baseyard, Waiohinu & -155.6150 & 19.0700 & 124 & 1365 & $\mathrm{C}$ & $1.5 \mathrm{ft}$ soil $/ 120 \mathrm{ft}^{\S}$ weathered basalt \\
\hline 2824 & $\begin{array}{l}\text { Mauna Loa Weather } \\
\text { Observatory }\end{array}$ & -155.5770 & 19.5363 & 318 & 1120 & $\mathrm{D}$ & $140 \mathrm{ft}$ soil/ $/ 130 \mathrm{ft}$ weathered basalt/basalt \\
\hline 2825 & Waimea Fire Station & -155.6614 & 20.0230 & 100 & 1375 & $\mathrm{C}$ & $16 \mathrm{ft}$ soil $/ 29 \mathrm{ft}$ weathered basalt/basalt \\
\hline 2826 & North Kohala Police Station & -155.8010 & 20.2300 & 198 & 1006 & $\mathrm{D}$ & $80 \mathrm{ft}$ soil $/ 60 \mathrm{ft}$ weathered basalt/basalt \\
\hline 2829 & Mauna Kea State Park & -155.5300 & 19.7520 & 192 & 1150 & $\mathrm{D}$ & $100 \mathrm{ft}$ soil $/ 30 \mathrm{ft}$ weathered basalt/basalt \\
\hline 2830 & Mauna Kea Summit & -155.4730 & 19.8260 & 156 & 1149 & $\mathrm{D}$ & $80 \mathrm{ft}$ soil/basalt \\
\hline 2832 & Honokaa Police Station & -155.4625 & 20.0775 & 154 & 1205 & $\mathrm{C}$ & $24 \mathrm{ft}$ soil $/ 66 \mathrm{ft}$ weathered basalt/basalt \\
\hline 2833 & Laupahoehoe Post Office & -155.2326 & 19.9835 & 172 & 1005 & $\mathrm{D}$ & $50 \mathrm{ft}$ soil $/ 122 \mathrm{ft}^{\S}$ weathered basalt \\
\hline 2834 & Mac Farms, Honomalino & -155.8680 & 19.1690 & 189 & 1086 & $\mathrm{D}$ & $120 \mathrm{ft}$ soil/basalt \\
\hline 2836 & $\begin{array}{l}\text { Hawaiian Volcano } \\
\text { Observatory }\end{array}$ & -155.2880 & 19.4200 & 156 & 890 & $\mathrm{D}$ & $130 \mathrm{ft}$ soft soil $/ 26+\mathrm{ft}$ soil \\
\hline 2839 & Hilo Medical Center & -155.1150 & 19.7220 & 202 & 1430 & $\mathrm{C}$ & $15 \mathrm{ft}$ soil $/ 80 \mathrm{ft}$ weathered basalt/basalt \\
\hline 2845 & Honaunau Post Office & -155.8805 & 19.4174 & 100 & 1559 & $\mathrm{C}$ & $100 \mathrm{ft}^{\S}$ weathered basalt \\
\hline 2846 & Mountain View Post Office & -155.1083 & 19.5504 & 123 & 1159 & $\mathrm{D}$ & $35 \mathrm{ft}$ soil $/ 88+\mathrm{ft}$ weathered basalt \\
\hline 2847 & $\begin{array}{l}\text { Waikoloa Marriott Hotel, } \\
\text { Anaehoomalu }\end{array}$ & -155.8870 & 19.9190 & 150 & 1550 & $\mathrm{C}$ & $26 \mathrm{ft}$ soil/basalt \\
\hline 2849 & $\begin{array}{l}\text { Kona Community Hospital, } \\
\text { Kea Lakekua }\end{array}$ & -155.9181 & 19.5215 & 200 & 1476 & $\mathrm{C}$ & $8 \mathrm{ft}$ soil/ $78 \mathrm{ft}$ weathered basalt/basalt \\
\hline 2852 & $\begin{array}{l}\text { South Kohala Fire Station, } \\
\text { Kamuela }\end{array}$ & -155.8343 & 19.9464 & 266 & 1902 & $\mathrm{C}$ & $3.5 \mathrm{ft}$ soil $/ 50.5 \mathrm{ft}$ weathered basalt/basalt \\
\hline 2853 & $\begin{array}{l}\text { NWS Data Regional Center, } \\
\text { Hilo }\end{array}$ & -155.0460 & 19.7154 & 203 & 1176 & $\mathrm{D}$ & $203 \mathrm{ft}^{\S}$ soil \\
\hline
\end{tabular}

$* V_{S 30}$ is computed from the $V_{S}$ profile. The number of significant digits does not reflect the uncertainty in these values.

${ }^{\dagger}$ NEHRP site class $V_{S 30}$ : A, $>5000 \mathrm{ft} / \mathrm{s} ; \mathrm{B}, 2500$ to $5000 \mathrm{ft} / \mathrm{s} ; \mathrm{C}, 1200$ to $2500 \mathrm{ft} / \mathrm{s} ; \mathrm{D}, 600$ to $1200 \mathrm{ft} / \mathrm{s} ; \mathrm{E},<600 \mathrm{ft} / \mathrm{s}$.

${ }^{\ddagger}$ Soil refers to stiff soil category shown in Figure 14. Weathered basalt refers to material category shown in Figure 13. Basalt refers to material category shown in Figure 12.

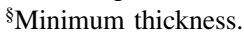

concentrations of red- and yellow-tagged houses in Waimea and Kapaau consistent with the recorded high PGAs (Earthquake Engineering Research Institute, 2006). Site response analyses, which are beyond the scope of this study, can be performed to quantify the shallow site-response effects.

Two strong-motion stations on the north coast, Honokaa Police Station and Laupahoehoe Post Office, and two stations on Mauna Kea were surveyed (Fig. 7). All four stations recorded significant PGA values given their hypocentral distances, with the highest PGA of $0.65 \mathrm{~g}$ recorded at Honokaa Police Station at a distance of $67 \mathrm{~km}$ (Fig. 1; Table 1). Three of the four stations are underlain by weathered basalt. All four stations have $V_{S}$ gradients in the soil and basalt with some significant impedance contrasts occurring at three of the stations. Honokaa Police Station has a jump in $V_{S}$ of 1690 to $2500 \mathrm{ft} / \mathrm{s}$ at a depth of $90 \mathrm{ft}$ (Fig. 7). This velocity contrast and gradient may explain the high recorded PGA value of $0.65 g$ (Fig. 1; Table 1). Mauna Kea State Park lies in a valley between Mauna Kea and Mauna Loa; this is reflected in the 100 feet of soil overlying $3000 \mathrm{ft} / \mathrm{s}$ basalt rock (Fig. 7). The $V_{S}$ profile atop Mauna Kea shows a steady increase in $V_{S}$ until unweathered basalt is reached at a depth of $80 \mathrm{ft}$ (Fig. 7). Shallow boreholes at one of the telescope sites drilled to a depth of $113 \mathrm{ft}$ revealed fine cinders with coarser materials (ground, cobbles, and boulders) occupying the bottoms of the holes.

Four strong-motion sites were surveyed in Hilo. These sites were about 96 to $100 \mathrm{~km}$ from the 2006 hypocenter (Fig. 1). The PGAs are modest except at the USDA Lab (Table 1; Fig. 1). Its PGA is a factor of 3 higher than the other two strong-motion stations (Table 1). The USDA Lab is a soft soil site (NEHRP site class E) located on ash/tephra at least down to a depth of $120 \mathrm{ft}$ with a $V_{S}<1000 \mathrm{ft} / \mathrm{s}$ (Fig. 8). In the 16 November 1983 M 6.6 Kaoiki earthquake, this same strong-motion site, then called the U.S. Fish and Wildlife station, also exhibited strong site amplification with factors of 5 to 6 at PGA compared with the neighboring University of Hawaii station (Buchanan-Banks, 1987). The Hilo Medical Center is reportedly also located on ash/ tephra according to Sherrod et al. (2007), although its $V_{S}$ profile indicates that the ash/tephra is not very thick if it is present at all (Fig. 8). 


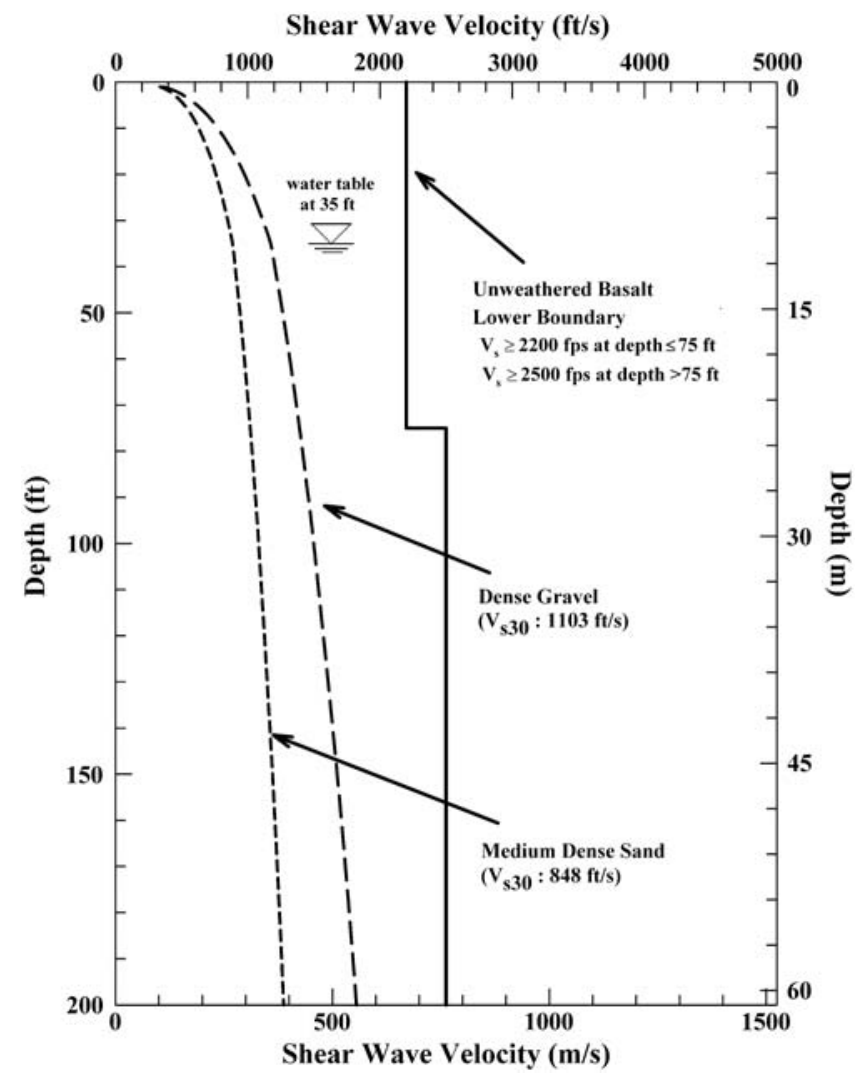

Figure 12. Template of $V_{S}$-depth relationships used to categorize geotechnical materials of the 22 sites.

Figure 9 shows the $V_{S}$ profiles of the three sites in the southeastern portion of the Big Island as well as at the Mauna Loa Weather Observatory. The $V_{S}$ profile at the HVO shows a thick layer of $1000 \mathrm{ft} / \mathrm{s}$ basalt with a $V_{S}$ jump at a depth of about $130 \mathrm{ft}$ (Fig. 9). We obtained our deepest $V_{S}$ profile at the Mauna Loa Observatory (Fig. 9). Firm basalt was not reached until a depth of $270 \mathrm{ft}$. All the stations recorded modest PGAs except for the Mauna Loa Observatory, which was much closer to the 2006 earthquake (Fig. 1; Table 1).

The four stations surveyed on the southern part of the Big Island are shown in Figure 10. Moderate PGAs of 0.13 to $0.18 \mathrm{~g}$ were recorded at three of the sites (Fig. 1). The Mac Farms station was not operational at the time. All the sites show low to moderate $V_{S}$ gradients in the basalt, although unweathered basalt is encountered at a depth of $120 \mathrm{ft}$ at Mac Farms (Fig. 10). We were only able to measure to a depth of $100 \mathrm{ft}$ at the Honaunau Post Office due to space limitations. The Ka'u Hospital velocity profile shows low velocity soil atop slowly increasing $V_{S}$ in basalt down to a depth of $286 \mathrm{ft}$ (Fig. 10).

Finally, two stations on the Kona Coast are shown in Figure 11. The Kona Community Hospital station in Kea Lakekau recorded a high PGA of $0.52 \mathrm{~g}$ (Fig. 1; Table 1). This was the fourth highest observed PGA, and the hospital sustained over half a million dollars of nonstructural damage in the earthquake. The hospital is located on a moderately steep hillside, which may account for some amplification. The $V_{S}$ profile shows a strong shallow gradient in the upper $45 \mathrm{ft}$ with two velocity jumps at 86 and $186 \mathrm{ft}$ depths (Fig. 11). This $V_{S}$ profile could also account for the fairly high PGA. We had space constraints at the Kailua-Kona Fire Station and low signal quality because of what we believe is artificial fill beneath the station hence limiting the maximum depth of the survey to only $100 \mathrm{ft}$ (Fig. 11). Unweathered basalt was encountered at a depth of $76 \mathrm{ft}$.

Based on observations of the strong-motion station nearsurface geology and the Geologic Map of the State of Hawaii by Sherrod et al. (2007), all but the two Hilo stations are assumed to be located on basalt. However, it is obvious that the map does not adequately identify the subsurface units as discussed previously. For example, the National Weather Service (NWS) Data Regional Center in Hilo is underlain by at least $200 \mathrm{ft}$ of stiff soil-like material (Table 3; Fig. 8). Given the location of the site near Hilo Bay, the soil may be largely alluvial in nature. Many of the basalt sites have soil thicknesses ranging up to more than $100 \mathrm{ft}$, for example, the HVO.

Based on the SASW survey results, all of the 22 USGS strong-motion sites are underlain by material with soil-like velocities with $V_{S 30}$ values ranging from $437 \mathrm{ft} / \mathrm{s}$ at the USDA Laboratory in Hilo (NEHRP site class E) to $1902 \mathrm{ft} / \mathrm{s}$ at the South Kohala Fire Station (NEHRP site class C) (Table 3). Twenty-one of the 22 strong-motion stations are either NEHRP site class C or D sites (Table 3 ). None of the strong-motion sites had rocklike $V_{S 30}$ values because of weathering, even sites where basalt outcropped at the surface, such as at the University of Hawaii at Hilo. However, note that the Waikoloa Marriott Hotel is essentially a rock site because of its high $V_{S}$ in the basalt beneath the thin (26 ft) soil layer (Fig. 6). In this case, the $V_{S 30}$ of $1550 \mathrm{ft} / \mathrm{s}$ (NEHRP site class C) is misleading in terms of its potential for site amplification.

Based on the NEHRP site-class assignments, the 2006 recorded PGA values are plotted in Figure 16 against the ground-motion prediction models of Youngs et al. (1997) for soil and Atkinson (2010) for a $V_{S 30}$ of $1272 \mathrm{ft} / \mathrm{s}$, the average value of the Big Island strong-motion sites. Although the 2006 data occupy a relatively narrow distance range of 39 to $118 \mathrm{~km}$, they are consistent with the Atkinson (2010) groundmotion prediction curves for an $\mathbf{M} 6.9$ at a depth of $38.9 \mathrm{~km}$, as might be expected given Atkinson (2010) used these data in the development of her model. The PGAs, however, show a large variability spanning the range encompassed by \pm one sigma (Fig. 16). The majority of the PGA values are above the median relationship of Youngs et al. (1997); hence, the hazard from deep earthquakes is probably underestimated in the 2001 USGS Hawaii hazard maps. Note the USDA Laboratory site (NEHRP site class E) exhibits the highest PGA of all stations in its distance range (Fig. 16), reflecting the strong amplification at this site due to the underlying ash deposits. 

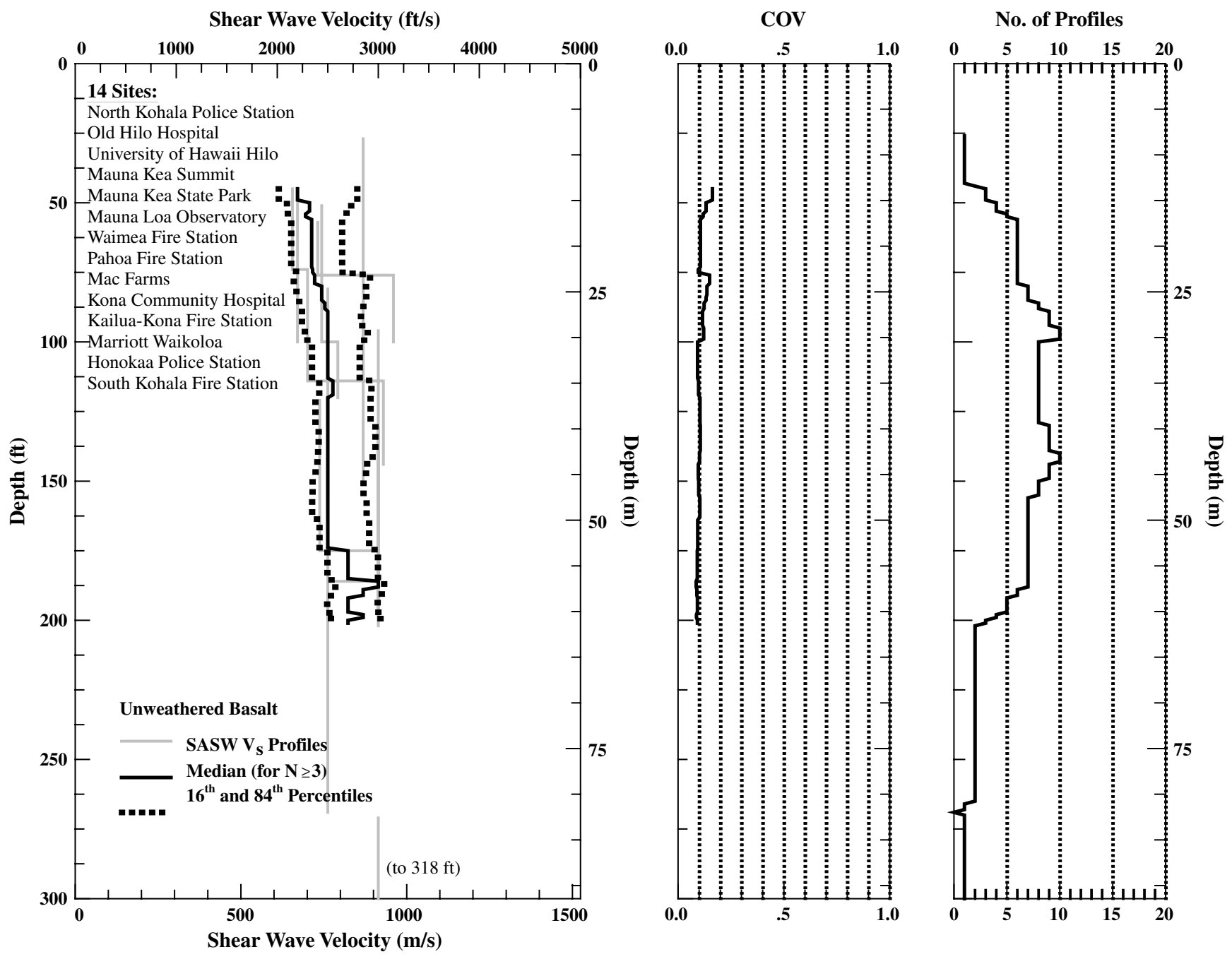

Figure 13. Statistical analysis of the unweathered basalt $V_{S}$ profiles.

Figure 17 compares the maximum recorded PGA versus $V_{S 30}$ and hypocentral distance. Within most of the $10-\mathrm{km}$ distance bin, there is no apparent trend of increasing PGA with decreasing $V_{S 30}$. This is most obvious in the 50-, 60-, and $90-\mathrm{km}$ distance bins (Fig. 17). The high PGA values recorded by the Waimea Fire Station (\#2826) and North Kohala Police Station (\#2825) are only marginally different, yet they are in different NEHRP site classes due to their differing $V_{S 30}$ values (Fig. 17). Hence, there must be other factors including source, path, and/or site effects beneath a depth of $30 \mathrm{~m}$ that are controlling the level of PGAs for this earthquake. In the $80 \mathrm{~km}$ distance bin, the USDA Laboratory site with its low $V_{S 30}$ shows the highest PGA as also indicated in Figure 16.

\section{Development of NEHRP Site-Class Map}

The first NEHRP site-class map for the Big Island was developed in 2006 by URS Corporation (see Data and Resources), but because no $V_{S}$ data were available for this desktop study, it was based solely on the Geologic Map of the Island of Hawaii by Wolfe and Morris (1996), updated by Sherrod et al. (2007), and limited geotechnical borehole data. As a result, based on the assumption that basalt would be rocklike, the map portrayed nearly all the Big Island as NEHRP site class B. The recent SASW surveys show this not to be true; rather, the 19 sites on basalt are classified as NEHRP site classes C or D (Table 3). Thus, we have developed a new 1:100,000-scale map of NEHRP site class for the Big Island. This new map, based largely on the SASW measurements, the 1:100,000-scale geologic mapping by Sherrod et al. (2007), and our past experience in measuring $V_{S}$ in similar materials (e.g., Wong and Silva, 2006; Wong et al., 2011) is shown in Figure 18.

To produce the NEHRP site-class map, $V_{S 30}$ measurements are related to geologic map units, then the geologic map is used as the basis for the NEHRP site-class map. The locations of SASW measurements were intersected with the most recent geologic map (Sherrod et al., 2007) in a geographic information system. All geologic map units in the map were then grouped into categories based on differences in $V_{S 30}$ measurements, for the units in which SASW data 

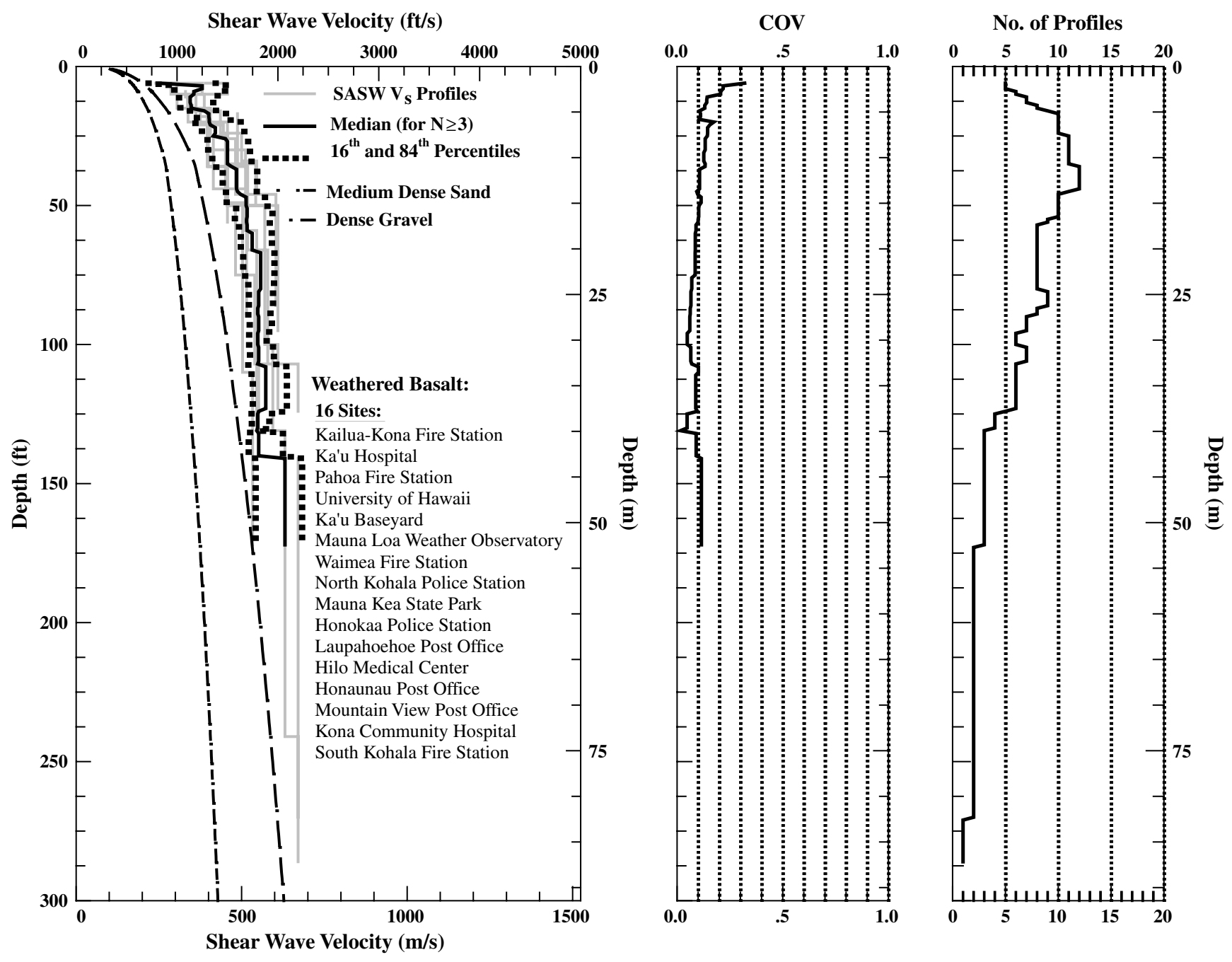

Figure 14. Statistical analysis of the partially weathered basalt $V_{S}$ profiles.

were collected, and based on assumed similarities in map units for the units in which SASW data were not collected. Table 2 shows the map unit groups, the number of SASW measurements for each group, and general statistics describing the suite of SASW measurements for each group. As is common for geological, geotechnical, and geophysical data, the data are not normally distributed (Fig. 19), and the variability between groups based on geologic map units can be as large as the variability within groups. However, the only map unit group for which sufficient SASW data are available to provide a reasonably robust characterization are basalts. Limited SASW data were collected in the other map unit groups (Table 2).

Areas of basalt (much of the island) should be considered NEHRP site class C or D in the new map (Knudsen et al., 2008). The 19 SASW-sampled sites cover a range of basaltic rock conditions, and the geologic map includes a range of units classified as basalt, including lava flows, scoria cones, littoral deposits, spatter or tuff cones, cinder cones, and lava domes. The median value for these $V_{S 30}$ estimates is $1365 \mathrm{ft} / \mathrm{s}$ with a standard deviation of $257 \mathrm{ft} / \mathrm{s}$ and a $\log$ mean of $1312 \mathrm{ft} / \mathrm{s}$. The variability in $V_{S 30}$ measurements in areas mapped as basalt may be a reflection of the wide range of map units lumped in the basalt map group. The variation may also be a result of differences in weathering profiles or in stratigraphy. Some areas mapped as basalt may be underlain by consistently hard basalt with few voids, whereas others may be underlain by layers of void-rich basalt interlayered with tephra layers. Clearly the $V_{S}$ profile in these two situations would be different, although the geologic map would not indicate such differences.

To attempt to subdivide areas mapped as basalt on the NEHRP site-class map, a number of parameters were tested to see if they controlled $V_{S 30}$ values. Among the parameters evaluated were age of map unit, source volcano, shield versus postshield volcano, and elevation. Perhaps the relatively small sample size $(n=19)$ does not provide sufficient data for a statistically valid comparison, but preliminary analyses suggest that none of these parameters correlate well with $V_{S 30}$.

Other geologic map unit groups used in generating the NEHRP site-class map, for which only one or two $V_{S 30}$ 

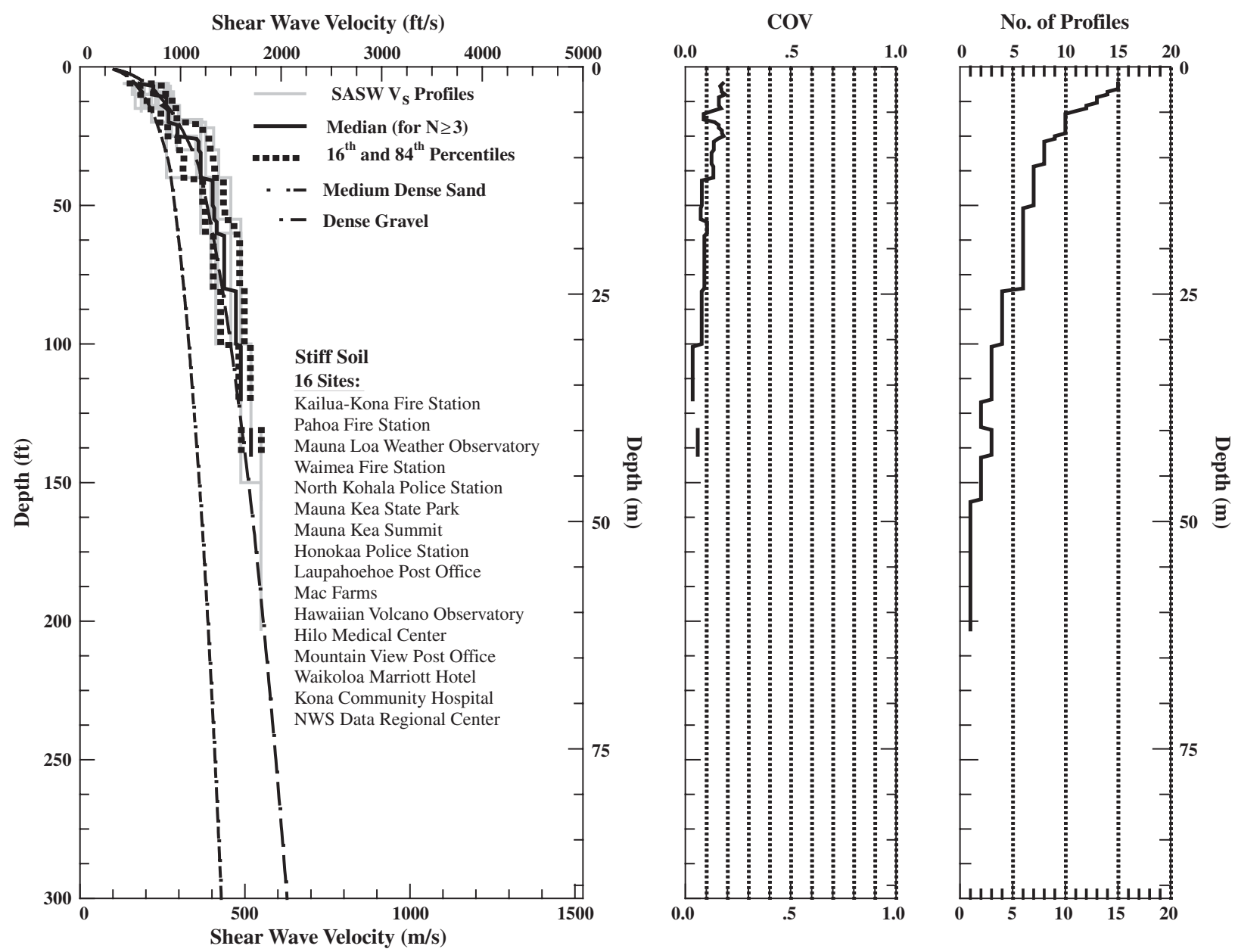

Figure 15. Statistical analysis of the stiff soil $V_{S}$ profiles.

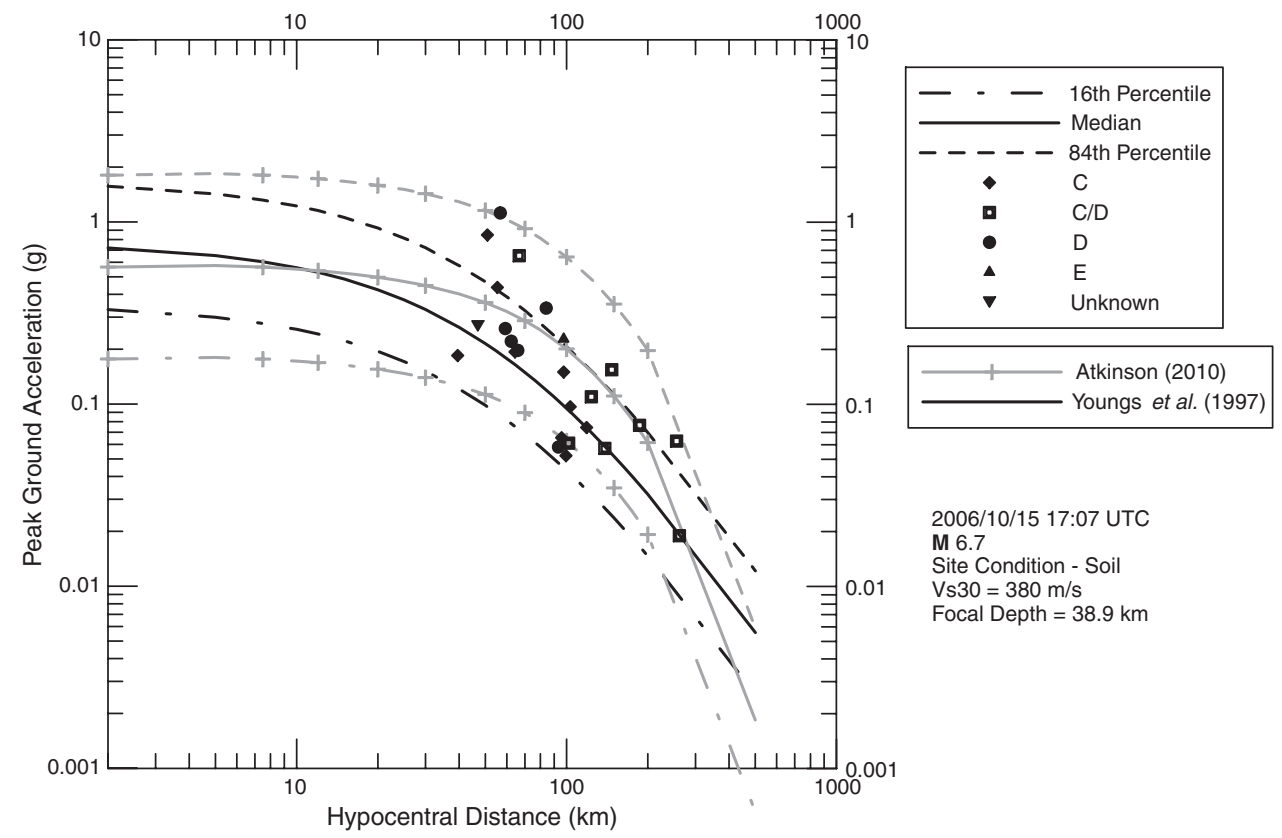

Figure 16. Comparison of Youngs et al. (1997) and Atkinson (2010) ground motion prediction models for soil ( $\left.V_{S 30} 1272 \mathrm{ft} / \mathrm{s}\right)$ and the recorded PGAs from the 2006 M 6.7 Kiholo Bay earthquake. 


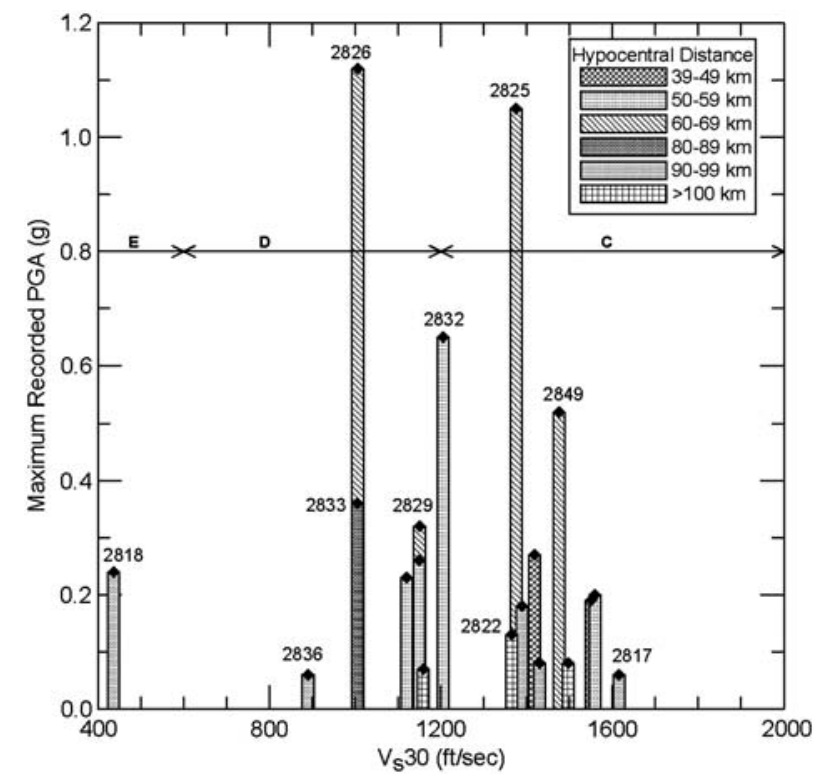

Figure 17. Maximum PGA versus $V_{S 30}$. Stations are binned by hypocentral distance. Selected stations are labeled (see Table 3). NEHRP site classes $\mathrm{C}, \mathrm{D}$, and $\mathrm{E}$ in terms of $V_{S 30}$ are also shown. estimates were made from SASW data, include alluvium $(n=1)$, ash/tephra $(n=2)$, and artificial fill $(n=2)$. These map unit groups were assigned NEHRP D or E, based on the available data and on a rudimentary understanding of the typical properties of these kinds of deposits (Table 2). Geologic deposits for which SASW data are not available include sand dunes, landslide deposits, and glacial deposits. The NEHRP site classes " $D$ " or " $C$ or D" were assumed for these units and used in the NEHRP site-class map (Fig. 18). Clearly, values for these parts of the site map are not well constrained.

\section{Conclusions}

Spectral-analysis-of-surface-waves surveys were performed at the 22 free-field strong-motion sites of the USGS Hawaii Strong Motion Network on the Big Island. $V_{S}$ profiles reaching depths ranging from 100 to $318 \mathrm{ft}$ were obtained. Most of the surveyed sites were located on basalt or weathered soil atop basalt and correspond to NEHRP site classes $\mathrm{C}$ or D. A qualitative examination of the $V_{S}$ profiles beneath the strong-motion sites suggests that the site effects

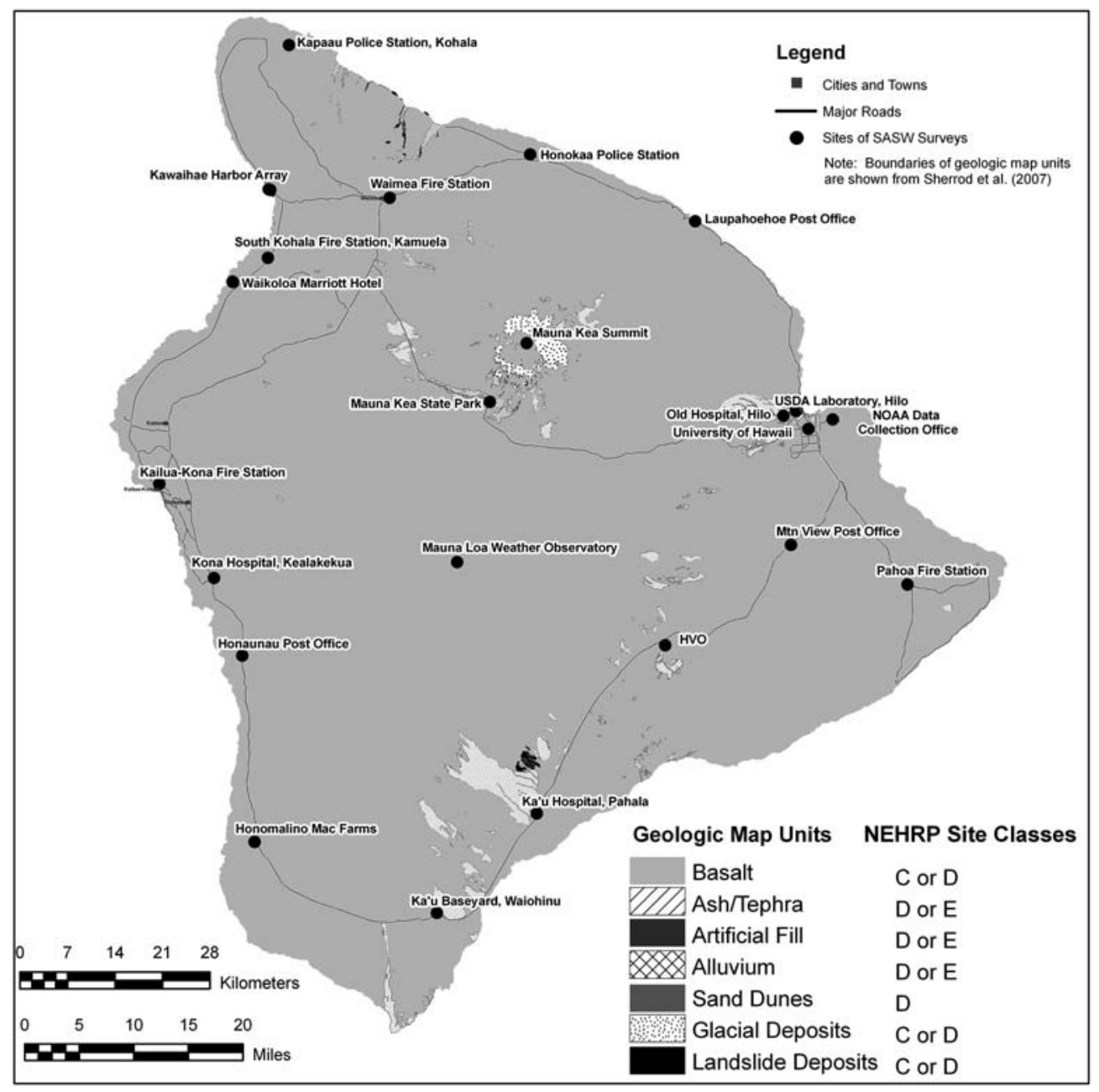

Figure 18. New NEHRP site-class map for the island of Hawaii. Geologic map units from Sherrod et al. (2007). 


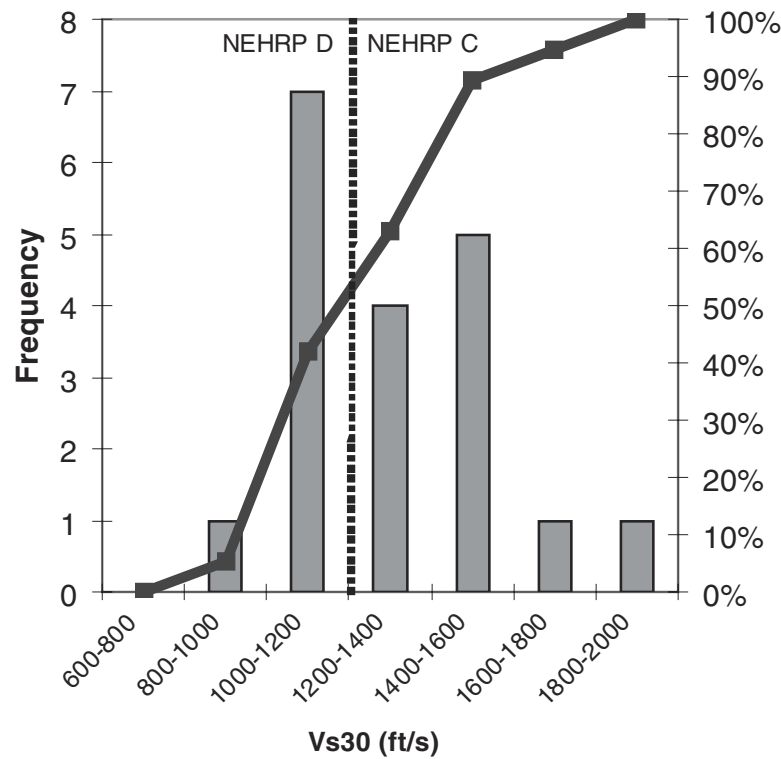

Figure 19. Distribution of $V_{S 30}$ for the 19 USGS strong-motion sites underlain by basalt as characterized by Sherrod et al. (2007). See Table 2 for statistics.

could be largely responsible for the observed ground motions in the 2006 Kiholo Bay mainshock, although other source and path factors may be coming into play.

The new NEHRP site-class map provides a more realistic foundation for ground-shaking hazard assessments than the previous map (URS Corporation; see Data and Resources), because it is based on SASW-based estimates of $V_{S 30}$. However, the limited number of SASW tests, the variability in $V_{S 30}$ values for geologic map unit groups, and the absence of SASW data for several of the map unit groups, show that more surveys and analyses would reduce the uncertainty in the map. Site-specific seismic hazard evaluations should be based on in situ $V_{S}$ surveys given the variability of $V_{S}$ we have observed on the Big Island.

\section{Data Resources}

Data from the USGS Hawaiian strong-motion network are available at http://nsmp.wr.usgs.gov (last accessed July 2011). The URS (2006) publication, "Developing a Hawaii NEHRP site class map for use in HAZUS-MH earthquake loss estimation, draft technical report for FEMA," U.S. Department of Homeland Security, is available only upon request to URS Corporation. The raw data from the SASW survey measurements and the template $V_{S}$ profiles can be obtained from the second author. The SASW-derived $V_{S}$ profiles are available from the first author.

\section{Acknowledgments}

Our sincere appreciation to Cecil Hoffpauir and Farn-Yuh Menq for assistance in the SASW surveys. Our thanks to Melinda Lee and Mark Dober for their assistance in the preparation of this paper, to Chris Stephens for providing us information on the North Kohala Police Station record, and to two anonymous reviewers for their constructive comments. Our appreciation to the property owners who allowed us access to perform the SASW surveys and to Edna Anjal, Woody Savage, and Roger Borcherdt of the USGS for assisting us in the access requests. The development of the SASW source "Thumper" was supported by the George E. Brown, Jr. Network for Earthquake Engineering Simulation (NEES) under NSF Grant CMS0086605. This study was supported by FEMA under Hazard Mitigation Technical Assistance Contract HSFEHQ-06-D-0162 and Technical Assistance and Research Contract HSFEHQ-04-D-0733, and by the U.S. Geological Survey, Department of the Interior, under USGS NEHRP grant award 08HQGR0036. The views and conclusions contained in this document are those of the authors and should not be interpreted as necessarily representing the official policies, either expressed or implied, of the U.S. Government.

\section{References}

Atkinson, G. M. (2010). Ground motion prediction equations for Hawaii from a referenced empirical approach, Bull. Seismol. Soc. Am. 100, 751-761.

Buchanan-Banks, J. M. (1987). Structural damage and ground failures from the November 16, 1983 Kaoiki earthquake, island of Hawaii, U.S. Geol. Surv. Profess. Pap. 1350, 1187-1220.

Earthquake Engineering Research Institute (EERI) (2006). Compilation of observations of the October 15, 2006 Kiholo Bay $\left(M_{\mathrm{w}}\right.$ 6.7) and Mahukona $\left(M_{\mathrm{w}} 6.0\right)$ earthquakes, Hawai'i, Chock, Gary ed., 53 pp.

Joh, S.-H. (1996). Advances in interpretation and analysis techniques for spectral-analysis-of-surface-waves (SASW) measurements, Ph.D. Thesis, University of Texas, Austin, Texas, 240 pp.

Klein, F. W., A. D. Frankel, C. S. Mueller, R. L. Wesson, and P. G. Okubo (2001). Seismic hazard in Hawaii: High rate of large earthquakes and probabilistic ground-motion maps, Bull. Seismol. Soc. Am. 91, 479-498.

Knudsen, K. L., I. G. Wong, and F. Terra (2008). A NEHRP site class map for the Island of Hawaii (abs.), Eos Trans. Am. Geophys. Union 89.

Lin, Y.-C., and K. H. Stokoe II (2008). Variability in $V_{S}$ profiles and consistency between seismic profiling methods: A case study in Imperial Valley, California, Proc. of the 3rd International Conf. on Site Characterization, ISC'3, A.-B. Huang and P. W. Mayne (Editors), Taipei, Taiwan, 1-4 April, 3, 218-224.

Menq, F. Y. (2003). Dynamic properties of sandy and gravelly soils, Ph.D. Thesis, University of Texas, Austin, Texas, 364 pp.

Munson, C. G., and C. H. Thurber (1997). Analysis of the attenuation of strong ground motion on the island of Hawaii, Bull. Seismol. Soc. Am. 87, 945-960.

Porter, S. C. (1997). Late Pleistocene eolian sediments related to pyroclastic eruptions of Mauna Kea volcano, Hawaii, Quaternary Research 47, 261-276.

Rosenblad, B. L., K. H. Stokoe, E. M. Rathje, and M. Darendeli (2001). Characterization of strong motion stations shaken by the Kocaeli and Duzce earthquake in Turkey, Geotechnical Engineering Report GR01-1, Geotechnical Engineering Center, University of Texas, Austin, Texas, $142 \mathrm{pp}$.

Sherrod, D. R., J. M. Sinton, and S. E. Watkins (2007). Geologic map of the State of Hawaii (sheet 8-Island of Hawaii), U.S. Geol. Surv. Open-File Rept. 2007-1089, scale 1:100,000.

Stephens, C. D., W. U. Savage, P. G. Okubo, and E. C. Anjal (2007). Update on strong-motion recordings of the October 15, 2006 M 6.7 Kiholo Bay, Hawaii, earthquake sequence (abs.), Seismol. Res. Lett. 78, 303-304.

Stokoe, K. H., S. H. Joh II, and R. D. Woods (2004). Some contributions of in situ geophysical measurements to solving geotechnical engineering problems, Proc. of the 2nd International Conf. on Site Characterization, ISC'2, A. Viana da Fonseca and P. W. Mayne (Editors), Porto, Portugal, 19-22 September, 1, 97-132.

Stokoe, K. H., B. L. Rosenblad II, J. A. Bay, B. Redpath, J. G. Diehl, R. Steller, I. G. Wong, P. A. Thomas, and M. Luebbers (2003). 
Comparison of $V_{S}$ profiles from three seismic methods at Yucca Mountain, in Soil and Rock America 2003, P. J. Culligan, H. H. Einstein, and A. J. Whittle (editors), Verlag Glückauf GMBH, Cambridge Massachusetts, 22-26 June, 1, 299-306.

Stokoe, K. H., S. G. Wright II, J. A. Bay, and J. M. Roesset (1994). Characterization of geotechnical sites by SASW method, in Technical Report-Geophysical Characterization of Sites, R. D. Woods (editor), prepared by ISSMFE Technical Committee 10, Oxford Publishers, 13th International Conf. on Soil Mechanics and Foundation Engineering, New Delhi, India, 5-10 January, 15-26.

Wolfe, E. W., and J. Morris (1996). Geologic map of the Island of Hawaii, U.S. Geol. Surv. Miscellaneous Investigations Series I-2524-A, scale $1: 100,000$

Wong, I., and W. Silva (2006). The importance of in situ shear-wave velocity measurements in developing urban and regional earthquake hazard maps, Proc. of the 19th Annual Symposium on the Application of Geophysics to Engineering and Environmental Problems, 2-6 April 2006, 1304-1315 (CD ROM).

Wong, I., K. Stokoe, B. Cox, F.-Y. Menq, C. Hoffpauir, and P. Okubo (2008). Shear-wave velocity profiling of the USGS strong motion stations on the Island of Hawaii (abs.), Seismol. Res. Lett. 79, 339.

Wong, I. G., K. H. Stokoe II, B. R. Cox, Y-C. Lin, and F-Y. Menq (2011). Shear-wave velocity profiling of strong motion sites that recorded the 2001 Nisqually, Washington, earthquake, Earthquake Spectra 27, $183-212$.

Youngs, R. R., S.-J. Chiou, W. J. Silva, and J. R. Humphrey (1997). Strong ground motion attenuation relationships for subduction zone earthquakes, Seismol. Res. Lett. 68, 58-73.
URS Corporation

Seismic Hazards Group

1333 Broadway, Suite 800

Oakland, California 94612

(I.G.W., K.L.K., F.T.)

University of Texas at Austin

Geotechnical Engineering Center

1 University Station C1793

Austin, Texas 78712

(K.H.S., J.Y., Y.-C.L.)

University of Arkansas

Department of Civil Engineering

4190 Bell Engineering Center 4155A

Fayetteville, Arkansas 72701

(B.R.C.)

USGS Hawaiian Volcano Observatory

Hawaii National Park

Hawaii 96718

(P.O.)

Manuscript received 7 October 2010 